\title{
Synergistic effect of UV radiation and nutrient limitation on Chlorella fusca (Chlorophyta) cultures grown in outdoor cylindrical photobioreactors
}

\author{
I. Malpartida ${ }^{1}$, C. G. Jerez ${ }^{1}$, M. M. Morales $^{2}$, P. Nascimento ${ }^{3}$, I. Freire ${ }^{3}$, J. Ezequiel ${ }^{4}$, \\ R. M. Rico ${ }^{1}$, E. Peralta ${ }^{1}$, J. R. Malapascua ${ }^{1}$, Y. Florez ${ }^{1}$, J. Masojidek ${ }^{5}$, \\ R. Abdala ${ }^{1}$, F. L. Figueroa ${ }^{1}$, E. Navarro ${ }^{6, *}$ \\ ${ }^{1}$ Departamento de Ecología, Facultad de Ciencias, Universidad de Málaga, 29071 Málaga, Spain \\ ${ }^{2}$ Department of Chemical Engineering, University of Almería, Almería, Spain \\ ${ }^{3}$ Department Microbiology and Parasitology, Faculty of Biology-CIBUS, University of Santiago de Compostela, \\ 15782 Santiago de Compostela, Spain \\ ${ }^{4}$ Departamento de Biologia and CESAM - Centro de Estudos do Ambiente e do Mar, Universidade de Aveiro, \\ Campus de Santiago, 3810-193 Aveiro, Portugal \\ ${ }^{5}$ Academy of Sciences, Institute of Microbiology, Opatovickýmlýn, 37981 Trĕboŭ, Czech Republic \\ ${ }^{6}$ Pyrenean Institute of Ecology (CSIC), Av. Montañana 1005, Zaragoza 50059, Spain
}

\begin{abstract}
This study assessed the interactive effects of UVR and nutrient depletion on Chlorella fusca cultures on the production and accumulation of particular biomolecules. To accomplish this, algae were grown for $5 \mathrm{~d}$ in outdoor thin-layer cascade cultivators under 3 nutrient treatments (full nutrients, $-\mathrm{N}$ and $-\mathrm{S}$ ) and then transferred to outdoor cylindrical photobioreactors for another $5 \mathrm{~d}$. Cultures were then exposed to full solar radiation (PAB) and decreased UVR. During the last $5 \mathrm{~d}$, bio-optical properties, photosynthetic activity, pigments, biochemical composition and oxidative stress were assessed. Initially, nutrient depletion caused changes in productivity and cell number in a manner that affected biochemical composition. After $3 \mathrm{~d}$, the percentage of lipids in the cultures under $\mathrm{N}$ deprivation reached values appropriate for being used as feed or food additives or for energy applications (35\% of lipid content), regardless of the light conditions. A longer exposure (5 d) resulted in interactive effects of light and nutrient conditions. Specifically, PAB increased lipid content in all cases (1.3- to 2.3-fold), but particularly under $\mathrm{S}$ deprivation. Longer exposure to $\mathrm{PAB}$ also increased oxidative stress in UVR and nutrient-limited treatments $(-\mathrm{N}$ and $-\mathrm{S})$. These results showed that the benefits expected from nutrient depletion (increase in biomolecule content e.g. lipids, carbohydrates and pigments) were modulated by the negative effects of algal UVR acclimation costs.
\end{abstract}

KEY WORDS: Bio-optic Chlorella fusca In vivo chlorophyll fluorescence $\cdot$ Photosynthetic pigments $\cdot$ UV radiation $\cdot$ Lipids $\cdot$ Lipid peroxidation $\cdot$ Proteins $\cdot$ Biochemical composition

\section{INTRODUCTION}

During the last $50 \mathrm{yr}$, microalgae have been cultivated in both out- and indoor systems to produce biomass used as food or feed or for the extraction of high-value molecules. Today, about 20 different

${ }^{*}$ Corresponding author: enrique.navarro@ipe.csic.es genera of algae are used to produce compounds of interest, including carotenoids, fatty acids, polysaccharides and antioxidant substances, or to obtain biofuels (Tredici 2010, Stengel et al. 2011, Wilhelm \& Jakob 2011, Sharma et al. 2012). Accordingly, the economic sectors impacted by such biotechnology

(C) The authors 2014. Open Access under Creative Commons by Attribution Licence. Use, distribution and reproduction are unrestricted. Authors and original publication must be credited. 
range from the food, cosmetic, energy, agri- and horticultural sectors to human health (De Pauw \& Persoone 1988, Stengel et al. 2011, Adarme-Vega et al. 2012). Microalgae are cultured using different systems, commonly called photobioreactors, which allow for the control of the environmental variables affecting algal growth. Changes from optimal conditions (i.e. in light quantity and quality and nutrient limitation) may result in algal stress, requiring biochemical and metabolic adjustments that may result in the synthesis and accumulation of some of these molecules of interest. A few reports are available on the effects of UVR, nutrient availability, or other physiological processes (oxidative stress, membrane damage, carbon [C] allocation and photosynthesis), considering species from the genus Chlorella (Malanga \& Puntarulo 1995), Nannochloropsis (Sobrino et al. 2005), Scenedesmus (Kasai \& Arts 1998, Germ et al. 2002), Platymonas (Yu et al. 2004) and the cyanobacteria Nostoc and Arthrospira (Helbling et al. 2006). To date, however, no study has focused on outdoor microalgal culture systems in the context of modifying both UVR intensity and nutrient availability.

In outdoor cultures, microalgae can be exposed to elevated irradiance $\left(>2000 \mu \mathrm{mol}\right.$ photons $\left.\mathrm{m}^{-2} \mathrm{~s}^{-1}\right)$ of photosynthetic active radiation (PAR, $\lambda=400$ to $700 \mathrm{~nm})$ and UVR $(\lambda=280$ to $400 \mathrm{~nm})$. Solar UVR is an environmental variable with a range of deleterious effects on microalgae. In particular, UVR, through different mechanisms, causes DNA damage (Buma et al. 1996, Helbling et al. 2006) and decreases C incorporation rates by reducing photosystem II (PSII) efficiency, the RUBISCO pool (McKenzie et al. 2011) and the carboxylation process (Beardall \& Raven 2004). However, positive effects involve the increase of $\mathrm{C}$ uptake under relatively low UVR levels (Nilawati et al. 1997, Barbieri et al. 2002) or DNA damage repair mediated by UVA radiation (Karentz et al. 1991). Indeed, many planktonic organisms are rather resistant to UVR, with only negligible cellular effects (Cabrera et al. 1997). Indirect effects might be viewed as positive, such as the breakdown of dissolved organic matter by UVR, which may result in an increase in nutrient supply. The vulnerability of plants to UVR is the result of a balance between photodamage, photoprotection and the photorepair mechanisms of DNA mediated by PAR and UVR (Mitchell \& Karentz 1993, Murata et al. 2007), to the accumulation of lipidic and water-soluble antioxidants and the activation of antioxidant enzymes (Cockell \& Knowland 1999) and to the accumulation of UV screen photoprotectors (Korbee et al. 2010). Since the irradiance of UVB radiation reaching Earth's surface is expected to change in the next decades (Hegglin \& Shepherd 2009, Watanabe et al. 2011), concerns have focused on assessing and forecasting the potential impacts of such changes on the productivity of cultivated plants (Schultz 2000, Golaszewski \& Upadhyaya 2003). In addition, because of the ecological and economic importance of algae and macrophyta, their responses to UVR have been extensively assessed in natural environments (Häder \& Figueroa 1997, Wulff et al. 2000, Helbling et al. 2003, Navarro et al. 2007, Pessoa 2012) and under artificial conditions (Sobrino et al. 2004, Korbee et al. 2010). Other studies demonstrated that algal acclimation to UVR entails metabolic costs in the form of reduced growth that may facilitate the effects of other stressors, such as heavy metals (Navarro et al. 2008). Furthermore, UVR may promote the accumulation of secondary metabolites in algae (i.e. high-value compounds), while reducing biomass productivity (Figueroa et al. 2008). In contrast, culture under artificial light or in greenhouses with UV cut-off filters reduces the accumulation of high-value compounds, but conversely, productivity can increase (Figueroa et al. 2006). Thus, although mass algal cultivation is concentrated at latitudes with high global solar exposure throughout the year (Tredici 2010, Acién Fernández et al. 2012), insufficient information is available about the effects of UVR on the productivity of outdoor microalgae cultures and even less is known about the synergistic effects of UVR and nutrient limitation.

Nutrient deprivation $(-\mathrm{S},-\mathrm{P},-\mathrm{N}$, etc.) results in a decrease of growth rate and photosynthetic rates by both direct (reduction of the synthesis of certain biomolecules) and indirect effects (reduction of protection or repair mechanisms). S is needed in protein synthesis (Grossman \& Takahashi 2001) but also in a wide range of secondary cell compounds, including glucosinolates and sulpholipids (Leustek \& Saito 1999). S deprivation may result in the cessation of algal cell division (Hase et al. 1959) and in the degradation of endogenous protein and starch (Melis et al. 2000, Zhang et al. 2002, Kosourov et al. 2003). The depletion of phosphate can increase photoinhibition and reduce the capacity for photoprotection against UV radiation (Carrillo et al. 2008). $\mathrm{N}$ is needed for the synthesis of proteins, and $\mathrm{N}$ deprivation increases the sensitivity of photosynthesis to UVR in several organisms (Litchman et al. 2002, Bouchard et al. 2008) due to less efficient repair of UVB damage that depends on $\mathrm{N}$ compounds. Fluorescence-based measurements of phytoplankton photosynthesis have been used to assess $\mathrm{N}$ limitation, which causes a decrease in the PSII photochemical quantum yield that 
reduces the efficiency of light-harvesting, energy transduction and $\mathrm{CO}_{2}$ fixation (Kolber et al. 1988, Berges et al. 1996, Geider et al. 1998, Young \& Beardall 2003). Aquatic organisms have several mechanisms to counteract and repair UVR effects, such as the accumulation of UV-absorbing substances with antioxidant properties, i.e. mycosporinelike amino acids (MAAs) (Shick \& Dunlap 2002), phenols and carotenoids (Goiris et al. 2012), or the effective dissipation of excess energy by the action of the xanthophyll cycle (Demmig-Adams \& Adams 1996). Therefore, a lack of $\mathrm{N}$ would decrease the rate of repair, slowly and progressively decreasing photosynthetic efficiency (Litchman et al. 2002).

Three different methods may lead to increased yield of algal biomolecules: (1) by increasing algal cell density, (2) by increasing the intracellular accumulation of such products or (3) a combination of both. While the first method may depend, largely, on the type of photobioreactor, the second and third may rely more on the growing conditions and stress to which algae are exposed. Therefore, knowledge about the effects of changes in culture conditions that may, in turn, change the synthesis and quantity of certain molecules would be of great interest for both basic and applied research.

In this study, Chlorella fusca (Chlorophyta) cultures were grown during $5 \mathrm{~d}$ in outdoor thin-layer cascade (TLC) cultivators under 3 nutrient treatments (full nutrients, $-\mathrm{N}$ and $-\mathrm{S}$ ). The cultures were then exposed to different light conditions, including full solar radiation $(\mathrm{PAB})$ or decreased UV radiation $(\mathrm{P}(\mathrm{AB}-))$. To evaluate the combined effect of UVR and nutrient depletion, different functional indicators were used (Figueroa et al. 2013). Based on the rationale previously presented, the working hypothesis was that the expected benefits from nutrient depletion (increase of certain biomolecules, such as lipids, carbohydrates and pigments) would be modulated by negative direct effects (i.e. algal acclimation costs) and decreased biomass productivity provoked by an increased exposure to UVR.

\section{MATERIALS AND METHODS}

\section{Experimental set-up}

Chlorella fusca (Chlorophyta, from the Spanish Collection of Algae) cultures were grown for $5 \mathrm{~d}$ in 3 outdoor TLC systems $\left(4 \mathrm{~m}^{2}\right.$ ) (see description in Jerez et al. 2014, this Theme Section) and acclimated to different nutrient conditions, i.e. full nutri- ents $(\mathrm{F})$, limited nitrogen $(-\mathrm{N})$ and limited sulphur $(-\mathrm{S})$. Full media contained the following $\left(\mathrm{g} \mathrm{l}^{-1}\right)$ according to Sorokin \& Krauss (1958): $\mathrm{KNO}_{3}, 1.25$; $\mathrm{KH}_{2} \mathrm{PO}_{4}, \quad 1.25 ; \quad \mathrm{MgSO}_{4} \cdot 7 \mathrm{H}_{2} \mathrm{O}, \quad 1 ; \mathrm{CaCl}_{2}, 0.0835$; $\mathrm{FeSO}_{4} \cdot 7 \mathrm{H}_{2} \mathrm{O}, 0.0498 ; \mathrm{H}_{3} \mathrm{BO}_{3}, 0.1143 ; \mathrm{ZnSO}_{4} \cdot 7 \mathrm{H}_{2} \mathrm{O}$, 0.0882; $\mathrm{MnCl}_{2} \cdot 4 \mathrm{H}_{2} \mathrm{O}, 0.0142 ; \mathrm{MoO}_{3}, 0.0071 ; \mathrm{CuSO}_{4}$. $5 \mathrm{H}_{2} \mathrm{O}, 0.0157 ; \mathrm{Co}\left(\mathrm{NO}_{3}\right)_{2} \cdot 6 \mathrm{H}_{2} \mathrm{O}, 0.0049$ and EDTA, 0.5 . The $-\mathrm{N}$ treatment received only $25 \%$ of the initial nitrate concentration, while the $-\mathrm{S}$ treatment received $50 \%$ of the normal sulphate concentrations. After this acclimation period, samples of $1.25 \mathrm{l}$ from each treatment were transferred to 18 UVRtransparent methacrylate cylinders (diameter $10 \mathrm{~cm}$, height $20 \mathrm{~cm}$ ) (see Aphalo et al. 2012). Strong aeration was applied to keep high hydrodynamic conditions in both the TLC tank (see Jerez et al. 2014) and the cylinders. Cultures in cylinders were maintained for $5 \mathrm{~d}$.

Two different light conditions were set: (1) full solar radiation (natural conditions), i.e. PAR+UVA+ UVB (PAB), and (2) decreased natural UVA+UVB $(\mathrm{P}[\mathrm{AB}-])$ by using cut-off filters surrounding the methacrylate cylinders (Ultraphan 395) according to Villafañe et al. (2003). The PAR irradiance in $\mathrm{PAB}$ was the same as in $\mathrm{P}(\mathrm{AB}-)$ by use of the cutoff filter Ultraphan 295 (Villafañe et al. 2003, Aphalo et al. 2012). This design avoided any problem caused from having different PAR irradiances, e.g. differences in photoinhibition (Villafañe et al. 2003). As a result, algal cultures in PAB vessels were exposed to $75 \%$ of incident UVB and UVA radiation, whereas cultures in $\mathrm{P}(\mathrm{AB}-)$ vessels were exposed to $8 \%$ of UVB and UVA. Daily temperature variations were minimized ( 25 to $28^{\circ} \mathrm{C}$ ) by placing the cylinders in a thermostatically controlled water bath (Fig. 1). Three replicates were set up for each treatment.

\section{Solar radiation, temperature and $\mathrm{pH}$ measurements}

Temperature was monitored using a HOBO Pro v2 Water Temperature Logger U22-001. The $\mathrm{pH}$ was measured using a portable $\mathrm{pH}$ meter $(\mathrm{pH} 3110$, WTW). Incident solar irradiance was measured continuously in air using a UV-PAR multifilter radiometer NILU UV6 (Geminali). The irradiance of UVA (320 to $400 \mathrm{~nm}$ ) and UVB (280 to $320 \mathrm{~nm}$ ) was calculated from the data of the different UV filters according to Høiskar et al. (2003). The integrated daily irradiance $\left(\mathrm{kJ} \mathrm{m}^{-2}\right)$ was calculated for the whole duration of the experiment. The NILU UV6 is located on the roof of the building housing the Central Services 


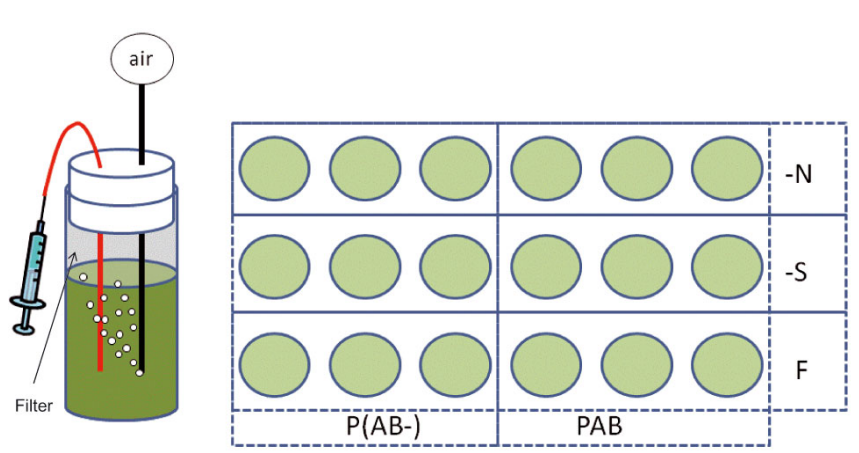

Fig. 1. Left: diagram showing the algal culture vessels equipped with an outlet syringe for sampling algal cultures and surrounded with UV cut-off filters, such as Ultraphan 295 (PAB) and Ultraphan 395 in the $\mathrm{P}(\mathrm{AB}-)$ treatment. The cultures were kept under agitation by air bubbling. Right: the experimental setup of the vessels in the thermostatic bath. F: full nutrients; $-\mathrm{N}$ : nitrogen-limited; $-\mathrm{S}$ : sulphurlimited; $\mathrm{PAB}$ : full solar radiation and $\mathrm{P}(\mathrm{AB}-)$ with the same PAR but decreased UVR. The position of the vessels was not randomly selected to facilitate daily measurement protocols. No temperature or light gradients were noticed in the bath

Research of Malaga University, where the experiments were conducted $\left(36^{\circ} 40^{\prime} \mathrm{N}, 4^{\circ} 28^{\prime} \mathrm{W}\right)$.

\section{Bio-optical variables: PAR and UVR extinction}

The irradiance of UVR (295 to $400 \mathrm{~nm}$ ) reaching different depths in the algal cultures was measured using a UV203 radiometer (MACAM, Scotland) connected to UV-B ( $\lambda_{\max }=295 \pm 2 \mathrm{~nm}$, bandpass FWHM $=19 \pm 2 \mathrm{~nm})$ or UV-A $\left(\lambda_{\max }=365 \pm 2 \mathrm{~nm}\right.$, bandpass FWHM $=35 \pm 2 \mathrm{~nm}$ ) sensors, following the procedures described in Navarro et al. (2014). In short, the algal suspensions were added to the upper part of a $50 \mathrm{ml}$ Uthermöl chamber fixed over the sensor; this part is a tube $95 \mathrm{~mm}$ in length and $25 \mathrm{~mm}$ diameter made with plastic that is opaque to UVR wavelengths. A bit of silicon was used around the bottom of the tube, just making contact with the glass surface of the sensors, in order to avoid leaching of the cell suspension. The natural sunlight UVA and UVB were measured before adding $5 \mathrm{ml}$ suspension aliquots to completely fill the column. Each aliquot increased the height of the suspension column by $1 \mathrm{~cm}$, allowing UVA and UVB intensity data to be plotted as a function of depth (see details in Navarro et al. 2014). The UVR irradiance was calculated using the following equation: $\left(\mathrm{UVA}_{\text {irradiance }} \times 2.94\right)+$ $\left(\mathrm{UVA}_{\text {irradiance }} \times 1.17\right)_{\text {; }}$ these constants were used to correct for the sensor's underestimation under the optic conditions of the measuring set-up. The PAR extinction was measured at different depths $(0.4$ and $3.5 \mathrm{~cm}$ ) of algal suspensions using a spherical quan- tum sensor (US-SQS/L, Walz). The extinction coefficients $K_{\mathrm{d}, \mathrm{UVR}}$ and $K_{\mathrm{d} \text {,PAR }}$ were estimated by adjusting the UVR and PAR measured irradiances to the BeerLambert equation.

The specific attenuation coefficient $K_{\mathrm{c}}$ was calculated for both PAR and UVR $\left(K_{\mathrm{C}, \mathrm{PAR}}\right.$ and $\left.K_{\mathrm{c}, \mathrm{UVR}}\right)$. This is an apparent optical property of cell cultures since it considers both the effect of cell size and pigment content on light absorption (Figueroa et al. 1997) and is expressed as $\mathrm{m}^{2} \mathrm{mg} \mathrm{chl} a^{-1}$.

\section{UV index}

In this study, we assessed the UVR screening capacity of algal cells, by measuring the absorbance of cell pigment extracts in the range of UVR wavelengths. That was done using a spectrophotometer (Shimadzu UV-16-03). The absorbances at 3 different wavelength bands (UVR: 295-400 nm, UVA: 320-400 nm, UVB: 295-320 nm) were measured from the pigment extract. Examination of the whole UVR-absorbance range is expected to integrate and reflect any UVR-induced change in the pigment composition of the algal community (Navarro et al. 2007). This UVR index has been previously tested for algal communities and pure cultures (Navarro et al. 2007). In short, the relative proportion of UVR absorbance to chl a was calculated as the ratio of absorbance intensity over the range of UVR to that of chl $a$ at $665 \mathrm{~nm}$. The area under the absorbance curve in the range of 295 to $400 \mathrm{~nm}$ was calculated by the sum of light absorbance at any wavelength (1 $\mathrm{nm}$ step). The resulting UVR ratio is a dimensionless number, representing a ratio between the absorbance capacities of the UVR-absorbing compounds per absorbance-unit of chl a (Navarro et al. 2007). The same procedure was used to calculate UVA and UVB ratios.

\section{Algal biomass and photosynthetic pigments}

Algal biomass was expressed as cell numbers $\mathrm{ml}^{-1}$ assessed using Neubauer chambers according to Utermöhl (1958). Total chlorophyll ( $a$ and $b$ ) and carotenoids were estimated spectrophotometrically by adding $2 \mathrm{ml}$ of dimethylformamide (DMF) to $1 \mathrm{mg}$ of freeze-dried sample, which was kept overnight in darkness at $4^{\circ} \mathrm{C}$. Then, the sample was centrifuged and analyzed at different wavelengths $(750,664$, 647 and $480 \mathrm{~nm}$ ) with a UV-Vis spectrophotometer (Shimadzu UV-16-03). The concentrations of chl a 
and $b$ as well as total carotenoids were calculated according to Wellburn (1994). The results were expressed as $\mu \mathrm{g} \mathrm{mg}^{-1}$ of biomass.

\section{Functional variables: photosynthetic activity as in vivo chl a fluorescence}

Photosynthetic performance was measured using pulse-amplitude-modulated (PAM) chl a fluorescence of photosystem II (Schreiber et al. 1995). The recommendations of Kromkamp \& Forster (2003) were followed for nomenclature. Effective quantum yield $\left(\Delta F / F_{\mathrm{m}}{ }^{\prime}\right)$, as defined by Genty et al. (1989), was measured in situ from outside the culture using a Pocket-PAM fluorometer (Gademann Instruments) by placing the optical fiber directly into the wall of the experimental vessel, as reported by Figueroa et al. (2013). At the same time, the photon fluence rate of PAR inside the cylinders was measured with a spherical quantum sensor (US-SQS; Walz). Both measurements were performed on the third and fifth day of the experiment at $3 \mathrm{~cm}$ depth from the culture surface 3 times a day: morning (09:00 h), noon (13:00 h) and evening (18:00 h).

Rapid light curves (RLCs) were constructed using a Junior-PAM fluorometer (Walz) twice a day (12:00 and 18:00 h) by sampling $10 \mathrm{ml}$ of cultures and transferring them to light-protected chambers for dark adaptation (15 min) to obtain optimal quantum efficiency $\left(F_{\mathrm{v}} / F_{\mathrm{m}}\right)$. Samples were exposed for $20 \mathrm{~s}$ to 12 increasing $E_{\text {PAR }}$ levels between 0 and $1500 \mu \mathrm{mol}$ photons $\mathrm{m}^{-2} \mathrm{~s}^{-1}$, which were provided by the internal blue LED of the fluorometer. Relative electron transport rates (rETR) were determined as follows:

$$
\mathrm{rETR}=\Delta F / F_{\mathrm{m}}{ }^{\prime} \times E_{\mathrm{PAR}}
$$

where $\Delta F / F_{\mathrm{m}}{ }^{\prime}$ is the effective yield where $\Delta F=F_{\mathrm{m}}{ }^{\prime}-$ $F_{\mathrm{t}}, F_{\mathrm{m}}{ }^{\prime}$ is the maximal fluorescence after saturation light pulse $\left(<4000 \mu \mathrm{mol}\right.$ photons $\left.\mathrm{m}^{-2} \mathrm{~s}^{-1}\right)$, and $F_{\mathrm{t}}$ is the intrinsic fluorescence of light-exposed algae. $E_{\mathrm{PAR}}$ ( $\mu$ mol photons $\mathrm{m}^{-2} \mathrm{~s}^{-1}$ ) is the photon fluence rate of PAR determined by a US-SQS spherical quantum sensor. Unless the number of absorbed quanta is known, it is not possible to give absolute ETR values as an estimation of production. However, RLCs presented as rETR values vs. irradiance can provide data about the relative change of photosynthetic activity under experimental conditions. Therefore, rETR values were fitted according to Eilers \& Peeters (1988), using least square error calculation and the Solver function of Excel (Microsoft) to obtain photosynthetic parameters, i.e. photon-capturing efficiency of PSII in the light-limited range $\left(\alpha_{\text {ETR }}\right), \mathrm{rETR}_{\max }$ and the light saturation coefficient $\left(E_{\mathrm{k}}\right)$.

\section{Biochemical composition}

Total $\mathrm{C}$ and total $\mathrm{N}$ were determined from dry biomass, using a CNH Perkin-Elmer 2400 elemental analyzer in which $\mathrm{C}$ was oxidized at $600^{\circ} \mathrm{C}$, and resulting peaks were compared with a known mass of an acetanilide standard to determine mass. Acetanilide has a composition of $71.09 \% \mathrm{C}$ and $10.36 \% \mathrm{~N}$. The $\mathrm{C}$ and $\mathrm{N}$ values were expressed as a percentage of dry weight biomass.

Soluble proteins were analyzed using the Bradford method (Bradford 1976): $20 \mu \mathrm{l}$ of sample supernatant from the cellular extracts and $235 \mu \mathrm{l}$ of Bradford reagent were added into each well of a 96 well plate and given $45 \mathrm{~min}$ to react. The protein levels were quantified in a plate reader (Multiskan FC, Thermo Fisher Scientific) with absorption readings at $595 \mathrm{~nm}$. The total protein concentration in samples was calculated from a standard curve ( 0 to $250 \mu \mathrm{g} \mathrm{ml}^{-1}$ ) made with bovine serum albumin and expressed as $\mathrm{mg}$ of protein per ml of extract.

Lipid content (\% of dry wt) was measured using the sulpho-phospho-vanillin method (Knight et al. 1972, Izard \& Limberger 2003). Concentrated sulphuric acid ( $2 \mathrm{ml} \mathrm{H}_{2} \mathrm{SO}_{4}$ ) was added to a blank in a tube containing $100 \mu \mathrm{l}$ of $80 \%$ methanol, to tubes with a triolein standard $(100 \mu \mathrm{l})$ and to tubes with $100 \mu \mathrm{l}$ of sample supernatant. Each tube was incubated for $30 \mathrm{~min}$ at $100^{\circ} \mathrm{C}$ and then cooled to room temperature in a water bath. After the addition of $5 \mathrm{ml}$ of phosphovanillin reagent, the tubes were incubated at room temperature for $15 \mathrm{~min}$. Absorbance was read on a spectrophotometer at $530 \mathrm{~nm}$ (Shimadzu UV-16-03).

Lipid peroxidation was calculated using the thiobarbituric acid reactive substances (TBARS) method after Heath \& Packer (1968). Samples for lipid peroxidation were collected on the first and fifth day of the experiment. From each cylinder, $15 \mathrm{ml}$ of algal suspension were collected and centrifuged. The supernatant was discarded, and the cellular pellet was frozen at $-80^{\circ} \mathrm{C}$. Each sample was resuspended in $2 \mathrm{ml}$ of cold extraction buffer $\left(50 \mathrm{mM} \mathrm{KH} \mathrm{KO}_{4}\right.$; $0.1 \mathrm{mM}$ EDTA; $0.1 \%$ Triton X-100, pH = 7.4) with butylated hydroxytoluene (BHT) $\left(40 \mu \mathrm{ml}^{-1}\right)$. Extraction was done by sonication (3 cycles of $30 \mathrm{~s}$, with $30 \mu \mathrm{m}$ amplitude, on ice) on a U200S control sonicator (IKA-Werke, Staufen). Then, $2 \mathrm{ml}$ of $0.5 \%$ thiobarbituric acid in $20 \%$ trichloroacetic acid were added to cell extracts. The mixture was heated for $30 \mathrm{~min}$ at 
$90^{\circ} \mathrm{C}$ and immediately put on ice, followed by centrifugation. TBARS absorption peak and unspecific turbidity were read at 532 and $600 \mathrm{~nm}$, respectively. Absorption readings were done on a dual-beam spectrophotometer (HALO DB-20, Dynamica). TBARS concentration was calculated from a tetraethoxypropane standard curve ( 0 to $250 \mu \mathrm{M}$ ) and expressed as nmolcell ${ }^{-1}$.

In all cases, at least 1 sample per cylinder was analyzed (i.e. minimum 3 replicates per treatment).

\section{Statistical analysis}

Most of the statistical analyses were performed with R statistical computing software (www.r-project. org). Unless otherwise indicated, errors are expressed as standard deviation (SD). A combination of parametric and nonparametric statistics was used. Normality was tested with the Shapiro-Wilkinson test and the Fligner-Killeen test to determine homocedasticity. When variances were homogeneous, the Fisher test was used for comparisons. The Welch 2 -sample $t$-test was performed to compare the means when the normality assumption was satisfied, and the Wilcoxon range test was used when normality was not achieved. One-way, 2-way or 3-way ANOVAs were used to compare the treatments when normality and homocedasticity were satisfied, while the Kruskal-Wallis test was applied when they were not. Tukey HSD or Duncan's MRT post-hoc tests were applied to evaluate differences between treatments.

Light extinction curves were fitted to a 2-parameter exponential decay model, using $\mathrm{R}$ and the drc package to obtain the corresponding $K_{\mathrm{d}}$ values. The compPAR function was used to compare $K_{\mathrm{d}}$, using $t$-tests with p-values adjusted using Bonferroni correction for multiple tests. The null hypothesis was that the ratio equals 1 . The ratio was obtained by dividing $K_{\mathrm{d}}$ values (i.e. $K_{\mathrm{d} \text {,UVR }}$ PAR $-\mathrm{N} / K_{\mathrm{d}, \text { UVR }}$ PAR $-\mathrm{S}$ from Day 1). If the ratio significantly differed from 1, the null hypothesis was rejected, meaning those values were significantly different $(\mathrm{p}<0.05)$.

Pearson's correlation coefficient (r) was determined to define the extent of a linear correlation between the studied variables and was calculated using the Statistica software (v.7.0, Statsoft).

\section{RESULTS}

\section{Physico-chemical and bio-optical variables}

Daily integrated irradiance

The daily PAR, UVA and UVB integrated irradiance during the 5 experimental days is shown in Fig. 2. On the first day of the experiment (18 September 2012) the daily integrated irradiance of PAR and UVR was much lower than that on the remaining days as a result of cloudy conditions $\left(4065,472\right.$ and $24 \mathrm{~kJ} \mathrm{~m}^{-2}$ of PAR, UVA and UVB daily integrated irradiance, respectively). During the acclimation period (13 to 17 September 2012), PAR daily integrated irradiance ranged between 9330 and $9870 \mathrm{~kJ} \mathrm{~m}^{-2}$, and this value ranged between 7859 and $9074 \mathrm{~kJ} \mathrm{~m}^{-2}$ in the experimental period (19 to 23 September 2012, see Fig. 2). The UVA daily integrated irradiance during the acclimation period ranged between 1066 and $1124 \mathrm{~kJ}$ $\mathrm{m}^{-2}$ and between 899 and $1004 \mathrm{~kJ} \mathrm{~m}^{-2}$, while the UVB ranged between $50-55 \mathrm{~kJ} \mathrm{~m}^{-2}$ and $44-48 \mathrm{~kJ} \mathrm{~m}^{-2}$, respectively.

$\mathrm{pH}$

The $\mathrm{pH}$ of all cultures transferred to the cylinders showed similar values around $7.15 \pm 0.15$, essentially because $\mathrm{pH}$ was controlled by $\mathrm{CO}_{2}$ injection in the TLC systems. Once in the cylinders, the pH was not controlled. The $\mathrm{pH}$ was measured on the last day at 18:40 h. The $-\mathrm{S}$ deficiency provoked a significant

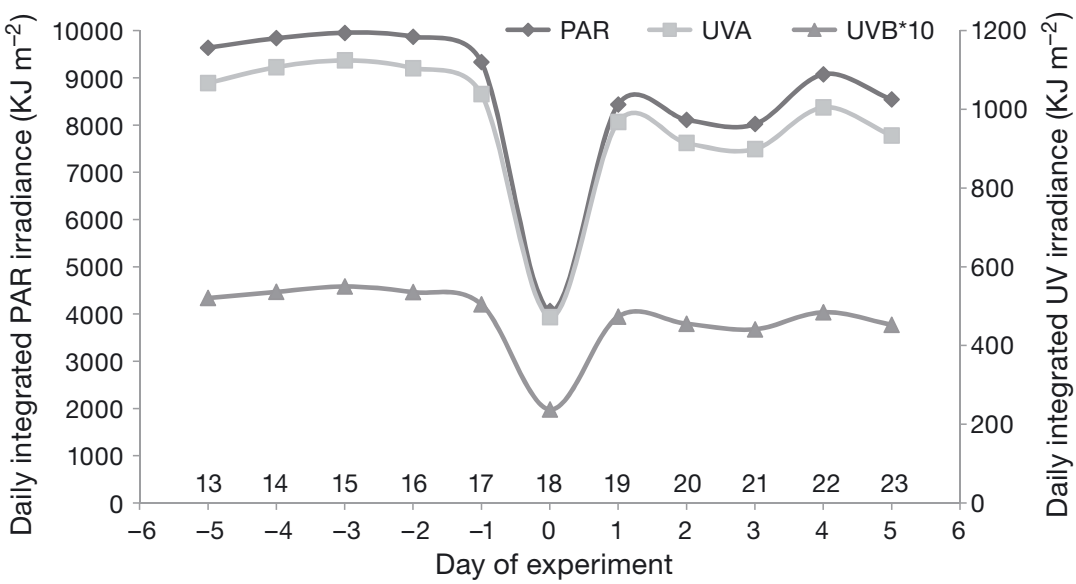

Fig. 2. Daily integrated irradiance of PAR (400 to $700 \mathrm{~nm}$ ), UVA (320 to $400 \mathrm{~nm}$ ) and UVB (280 to $320 \mathrm{~nm}$ ) during the experiment: preacclimation of cultures in thin-layer cascades (from 13 to 17 Sep); Day 0 (18 Sep), transfer from TLC to methacrylate cylindrical vessels; Day 1 to 5 (19 to 23rd Sep), experimental perriod. UVB irradiance values are multiplied by a factor of 10 for inclusion in the same scale as UVA. Numbers above the $x$-axis are dates in September 2012 
increase of $\mathrm{pH}$ in the algal culture with values around 7.8 to 8.0 , and this effect was significantly enhanced by UVR (data not shown). The $\mathrm{pH}$ in the other treatments was around 7.4, a value slightly higher than the initial one.

\section{Extinction coefficients}

After $3 \mathrm{~d}$ of growing in cylinders, $K_{\mathrm{d}, \mathrm{UVR}}$ and $K_{\mathrm{d}, \mathrm{PAR}}$ of the algal cultures increased (Table 1). Later on, $K_{\mathrm{d}, \text { UVR }}$ and $K_{\mathrm{d}, \mathrm{PAR}}$ slightly decreased or increased until the end of the experiment, always showing values higher than the initial ones. Statistical analysis was performed each day to compare different nutrient conditions, and no statistical differences were found in $K_{\mathrm{d}, \mathrm{UVR}}$ values. However, significant differences were shown along the time course such that Day 0 presented lower values than Day 5. Although intermediate values were shown for Day 3, these values were not significantly different from either Day 0 or 5. In the $\mathrm{P}(\mathrm{AB}-)$ treatment, $K_{\mathrm{d}, \mathrm{UVR}}$ values increased in all nutrient conditions except under $F$, where they decreased at Day 5. The highest value was found in -S at Day 5. Similarly, $K_{\mathrm{d}, \mathrm{UVR}}$ values in the PAB cultures increased throughout the experiment; $\mathrm{P}(\mathrm{AB}-)$ cultures also increased $K_{\mathrm{d}, \mathrm{UVR}}$, but to a lesser extent. In this case, the F conditions also showed a slight decrease at the end of the experiment.

$K_{\mathrm{d} \text { PAR }}$ was affected by changes in both light and nutrient conditions. $\mathrm{P}(\mathrm{AB}-)$ light conditions resulted in higher $K_{\mathrm{d}, \mathrm{PAR}}$. N-deprived cultures presented significantly lower $K_{\mathrm{d}, \mathrm{PAR}}$ values than the F treatments, while S-deprived algae presented intermediate values, which were not significantly different from the others.

Table 1. Number of cells, bio-optical properties and algal pigments during the experiment. Analyses were performed on Days 0,3 and 5 (see Figs. $1 \& 2$ for details and abbreviations). Parameters shown are biomass, expressed as number of cells $\left(\times 10^{6}\right.$ $\mathrm{ml}^{-1}$ ); UVR and PAR extinction coefficients expressed in $\mathrm{m}^{-1}$; $K_{\mathrm{c}}$ expressed as $\times 10^{7} \mathrm{~m}^{2} \mathrm{mg} \mathrm{chl}^{-1}$; chl $a$ and $b$ and total carotenoids expressed as $\mu \mathrm{g}$ of pigment per mg dry biomass. Two- (light $\times$ nutrients) or 3 -way (time $\times$ light $\times$ nutrient) ANOVAs have been performed per each parameter, depending on whether time was relevant or not and on the availability of replicates. Letters (a, $\mathrm{b}, \mathrm{c} .$. ) are used to denote differences (Tukey HSD tests, $\mathrm{p}<0.05$ ); treatments presenting values with same letter are not significantly different. Error terms are available only for those values obtained using replicates. Differences between extinction coefficients $\left(K_{\mathrm{d}}\right)$ have been tested by $t$-tests, and the results are detailed in the corresponding section. nd: not determined

\begin{tabular}{|c|c|c|c|c|c|c|}
\hline & & \multirow{2}{*}{$\begin{array}{c}\text { TLC } \\
\text { Day } 0\end{array}$} & \multicolumn{4}{|c|}{ — Light regime in cylinders } \\
\hline & & & Day 3 & Day 5 & Day 3 & Day 5 \\
\hline No. of cells & $\begin{array}{l}\mathrm{F} \\
-\mathrm{S} \\
-\mathrm{N}\end{array}$ & $\begin{array}{l}4.55 \\
11.5 \\
9.54\end{array}$ & nd & $\begin{array}{r}8.5 \pm 4.1^{\mathrm{a}} \\
10.1 \pm 1.3^{\mathrm{a}} \\
5.9 \pm 2.3^{\mathrm{a}}\end{array}$ & nd & $\begin{array}{l}7.9 \pm 3.2^{\mathrm{a}} \\
7.3 \pm 2.9^{\mathrm{a}} \\
5.5 \pm 1.8^{\mathrm{a}}\end{array}$ \\
\hline$K_{\mathrm{d}, \mathrm{UVR}}$ & $\begin{array}{l}\mathrm{F} \\
-\mathrm{S} \\
-\mathrm{N}\end{array}$ & $\begin{array}{l}129 \\
116 \\
109\end{array}$ & $\begin{array}{l}161 \\
146 \\
125\end{array}$ & $\begin{array}{l}130 \\
170 \\
143\end{array}$ & $\begin{array}{l}167 \\
162 \\
128\end{array}$ & $\begin{array}{l}163 \\
179 \\
176\end{array}$ \\
\hline$K_{\mathrm{d}, \mathrm{PAR}}$ & $\begin{array}{l}\mathrm{F} \\
-\mathrm{S} \\
-\mathrm{N}\end{array}$ & $\begin{array}{l}42 \\
40 \\
33\end{array}$ & $\begin{array}{l}45 \\
46 \\
42\end{array}$ & $\begin{array}{l}46^{\mathrm{a}} \\
50^{\mathrm{a}} \\
45^{\mathrm{a}}\end{array}$ & $\begin{array}{l}45 \\
38 \\
40\end{array}$ & $\begin{array}{l}47 \\
33 \\
39\end{array}$ \\
\hline$K_{\mathrm{c}, \mathrm{UVR}}$ & $\begin{array}{l}\mathrm{F} \\
-\mathrm{S} \\
-\mathrm{N}\end{array}$ & $\begin{array}{l}0.028 \pm 0.006^{b} \\
0.030 \pm 0.004^{b} \\
0.029 \pm 0.004^{b}\end{array}$ & $\begin{array}{l}0.120 \pm 0.03^{\mathrm{ab}} \\
0.119 \pm 0.03^{\mathrm{ab}} \\
0.092 \pm 0.04^{\mathrm{ab}}\end{array}$ & $\begin{array}{l}0.135 \pm 0.01^{\mathrm{ab}} \\
0.165 \pm 0.01^{\mathrm{a}} \\
0.097 \pm 0.01^{\mathrm{ab}}\end{array}$ & $\begin{array}{l}0.128 \pm 0.02^{\mathrm{ab}} \\
0.124 \pm 0.01^{\mathrm{ab}} \\
0.069 \pm 0.01^{\mathrm{ab}}\end{array}$ & $\begin{array}{l}0.164 \pm 0.02^{\mathrm{a}} \\
0.158 \pm 0.02^{\mathrm{ab}} \\
0.166 \pm 0.03^{\mathrm{a}}\end{array}$ \\
\hline$K_{\mathrm{C}, \mathrm{PAR}}$ & $\begin{array}{l}\mathrm{F} \\
-\mathrm{S} \\
-\mathrm{N}\end{array}$ & $\begin{array}{l}0.009 \pm 0.002 \\
0.011 \pm 0.001 \\
0.009 \pm 0.001\end{array}$ & $\begin{array}{l}0.033 \pm 0.008 \\
0.038 \pm 0.011 \\
0.031 \pm 0.016\end{array}$ & $\begin{array}{l}0.048 \pm 0.003 \\
0.048 \pm 0.003 \\
0.031 \pm 0.002\end{array}$ & $\begin{array}{l}0.035 \pm 0.004 \\
0.029 \pm 0.003 \\
0.022 \pm 0.002\end{array}$ & $\begin{array}{l}0.047 \pm 0.006 \\
0.029 \pm 0.004 \\
0.037 \pm 0.008\end{array}$ \\
\hline Chl a & $\begin{array}{l}\mathrm{F} \\
-\mathrm{S} \\
-\mathrm{N}\end{array}$ & $\begin{array}{l}8.18 \pm 0^{\mathrm{a}} \\
5.72 \pm 0^{\mathrm{b}} \\
5.83 \pm 0^{\mathrm{b}}\end{array}$ & $\begin{array}{l}2.69 \pm 0.81^{\mathrm{cd}} \\
2.59 \pm 0.84^{\mathrm{cd}} \\
2.73 \pm 1.62^{\mathrm{cd}}\end{array}$ & $\begin{array}{l}1.92 \pm 0.1^{\mathrm{d}} \\
2.06 \pm 0.12^{\mathrm{d}} \\
2.93 \pm 0.2^{\mathrm{cd}}\end{array}$ & $\begin{array}{c}2.59 \pm 0.32^{\mathrm{cd}} \\
2.81 \pm 0.09^{\mathrm{cd}} \\
3.7 \pm 0.35^{\mathrm{c}}\end{array}$ & $\begin{array}{l}1.98 \pm 0.26^{\mathrm{d}} \\
2.27 \pm 0.26^{\mathrm{cd}} \\
2.13 \pm 0.38^{\mathrm{d}}\end{array}$ \\
\hline Chl $b$ & $\begin{array}{l}\mathrm{F} \\
-\mathrm{S} \\
-\mathrm{N}\end{array}$ & $\begin{array}{r}4.36 \pm 0^{\mathrm{a}} \\
2.7 \pm 0^{\mathrm{ab}} \\
2.66 \pm 0^{\mathrm{ab}}\end{array}$ & $\begin{array}{l}2.06 \pm 0.26^{\mathrm{ab}} \\
1.75 \pm 0.51^{\mathrm{b}} \\
0.53 \pm 3.25^{\mathrm{b}}\end{array}$ & $\begin{array}{l}0.96 \pm 0.07^{b} \\
1.32 \pm 0.05^{b} \\
1.77 \pm 0.07^{b}\end{array}$ & $\begin{array}{l}1.86 \pm 0.31^{\mathrm{b}} \\
2.05 \pm 0.17^{\mathrm{ab}} \\
2.36 \pm 0.2^{\mathrm{ab}}\end{array}$ & $\begin{array}{l}0.99 \pm 0.02^{\mathrm{b}} \\
1.63 \pm 0.48^{\mathrm{b}} \\
1.81 \pm 0.41^{\mathrm{b}}\end{array}$ \\
\hline Carotenoids & $\begin{array}{c}\mathrm{F} \\
-\mathrm{S} \\
-\mathrm{N}\end{array}$ & $\begin{array}{l}3.86 \pm 0^{\mathrm{s}} \\
3.09 \pm 0^{\mathrm{b}} \\
3.06 \pm 0_{\mathrm{b}}\end{array}$ & $\begin{aligned} 0.45 & \pm 0.37^{\mathrm{de}} \\
0.5 & \pm 0.18^{\mathrm{de}} \\
0.76 & \pm 0.06^{\mathrm{cd}}\end{aligned}$ & $\begin{aligned} 0.42 & \pm 0.04^{\mathrm{de}} \\
0.38 & \pm 0.04^{\mathrm{c}} \\
0.6 & \pm 0.01^{\mathrm{cde}}\end{aligned}$ & $\begin{array}{c}0.61 \pm 0.08^{\text {cde }} \\
0.65 \pm 0.19^{\text {cde }} \\
0.9 \pm 0.16^{\text {c }}\end{array}$ & $\begin{array}{l}0.43 \pm 0.07^{\mathrm{de}} \\
0.45 \pm 0.05^{\mathrm{de}} \\
0.39 \pm 0.07^{\mathrm{e}}\end{array}$ \\
\hline
\end{tabular}


For $K_{\mathrm{C}, \mathrm{UVR}}$, both time and the interaction of time and light provoked significant differences between treatments. Day 0 presented significantly lower values of $K_{\mathrm{c}, \mathrm{UVR}}$ than Days 3 or 5 ; consequently, the results show the same general trend as with $K_{d}$, i.e. increasing values until the end of experiment for all the treatments. In detail, $K_{\mathrm{C}, \mathrm{UVR}}$ showed the highest values in $\mathrm{PAB} F$ and $-\mathrm{N}$. Although also higher, $\mathrm{PAB}$ $-\mathrm{S}$ values were closer to those of $\mathrm{P}(\mathrm{AB}-)-\mathrm{S}$. Higher values of $K_{\mathrm{C}, \mathrm{PAR}}$ were found in $\mathrm{PAB}-\mathrm{N}$ and $\mathrm{P}(\mathrm{AB}-)$ $-\mathrm{S}$. No differences between light conditions were found in the $\mathrm{F}$ treatments.

\section{UV index}

The different light conditions did not yield significant differences between treatments. Hence, values were grouped and analyzed according the nutrient condition prevailing during the experiment. Different nutrient conditions resulted in changes in the UVR index (Fig. 3). N depletion resulted in a reduction of UVR-screening capacity, caused by the reduction in the absorbance capacity in the UVA range. In contrast, no differences in UVR-screening capacity were detected, regardless of nutrient conditions.

\section{Pigment content}

During the acclimation period, chlorophyll and carotenoid content decreased in the nutrientdepleted treatments (see Day 0 in Table 1). The average chl a content under $\mathrm{F}$ was about $8 \mu \mathrm{g} \mathrm{mg} \mathrm{m}^{-1}$, decreasing to $5.77 \mu \mathrm{g} \mathrm{mg}{ }^{-1}$ in both the $-\mathrm{N}$ and $-\mathrm{S}$ treatments. A similar trend was found for $\operatorname{chl} b$ and carotenoids. These trends were even more marked after $3 \mathrm{~d}$ in the cylinders (exposed to different light conditions in addition to the nutrient treatment). Chl a decreased in all treatments, irrespective of nutrient or light conditions, except for in the PAB $-\mathrm{N}$ treatment which showed significantly higher values, although lower than in Day 0. Chl $b$ decreased in all treatments, and carotenoids showed very low concentrations. After $5 \mathrm{~d}$, chl a content still decreased, but when different treatments were compared, $\mathrm{P}(\mathrm{AB}-)$-N presented significantly higher chl a content than the others. In contrast, chl $b$ was affected by nutrient conditions: $-\mathrm{N}$ treatments presented the highest values and $\mathrm{F}$ the lowest, while $-\mathrm{S}$ presented intermediate values, although not statistically different. Although carotenoid content was generally very low, it was higher under $\mathrm{P}(\mathrm{AB}-)-\mathrm{N}$ conditions.
Biomass and growth

After the acclimation period in the TLC, the number of cells showed no statistical differences among nutrient treatments. However, $-\mathrm{N}$ and $-\mathrm{S}$ cultures presented higher values than F. After transferring cultures to the cylinders, the average cell number increased under $\mathrm{F}$ conditions but decreased under $-\mathrm{S}$ and $-\mathrm{N}$, although this difference was not statistically different. This effect was more marked in this last treatment, irrespective of light conditions (Table 1).

\section{Photosynthetic activity}

Maximal quantum yield $\left(F_{\mathrm{v}} / F_{\mathrm{m}}\right)$ presented similar values, both initially ( 0.61 to 0.62$)$ and after $5 \mathrm{~d}$ of culture in the TLC (Table 2), but significant differences were found after $5 \mathrm{~d}$ in cylinders. Under full nutrient conditions, $F_{\mathrm{v}} / F_{\mathrm{m}}$ did not change after $5 \mathrm{~d}$ in either light regime. However, significant differences were found by the end of the experiment under $-\mathrm{N}$ and $-\mathrm{S}$. For $-\mathrm{S}, F_{\mathrm{v}} / F_{\mathrm{m}}$ values did not vary under $\mathrm{P}(\mathrm{AB}-)$, but a decrease was observed under PAB after $5 \mathrm{~d}$. On the contrary, $F_{\mathrm{v}} / F_{\mathrm{m}}$ increased when $\mathrm{N}$-depleted cultures were exposed to $\mathrm{P}(\mathrm{AB}-)$, although no changes were observed in $\mathrm{PAB}$.

At the beginning of the experiment, rETR $_{\max }$ values obtained from the RLCs were lower under $F$ than in $-\mathrm{S}$ and $-\mathrm{N}$ conditions. Although $\mathrm{rETR}_{\max }$ under $\mathrm{F}$

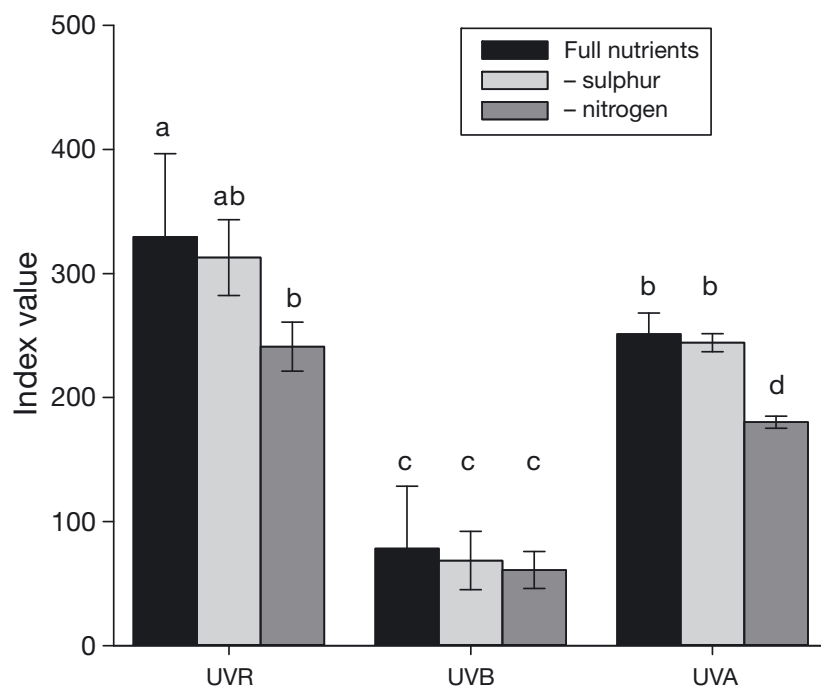

Fig. 3. UVR indexes as UVR (280 to $400 \mathrm{~nm}$ ), UVB (280 to $320 \mathrm{~nm}$ ) and UVA (320 to $400 \mathrm{~nm}$ ) for the different nutrient treatments at Day 5 combining both light treatments, PAB and $\mathrm{P}(\mathrm{AB}-)$, since no significant differences were found. Columns showing different letters indicate that differences are statistically significant, whereas the use of the same letter indicates no differences 
Table 2. Maximal quantum yield $\left(F_{\mathrm{v}} / F_{\mathrm{m}}\right)$ and the ETR parameters obtained from the rapid light curves as maximal relative ETR $\left(\mathrm{rETR}_{\max }, \mu \mathrm{mol} \mathrm{e}^{-} \mathrm{m}^{-2} \mathrm{~s}^{-1}\right)$, photosynthetic efficiency $\left(\alpha_{\mathrm{ETR}}\right)$, saturated irradiance $\left(E_{\mathrm{k}}, \mu \mathrm{mol}\right.$ photons $\left.\mathrm{m}^{-2} \mathrm{~s}^{-1}\right)$ and $\mathrm{rETR}$ at noon

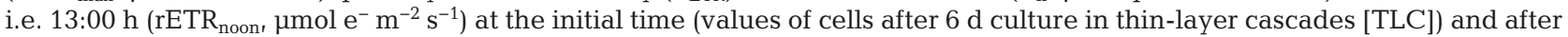
3 and $5 \mathrm{~d}$ under the different nutrient regimes, including full nutrients $(\mathrm{F})$, sulphur $(-\mathrm{S})$ and nitrogen $(-\mathrm{N})$ starvation, as well as different light treatments, including natural solar radiation with a $295 \mathrm{~nm}$ cut-off filter (PAB) and reduced UVR using a 395 $\mathrm{nm}$ cut-off filter, i.e. $\mathrm{P}(\mathrm{AB}-)$. Three-way ANOVA (time $\times$ light $\times$ nutrient) has been performed for each parameter. Letters $(\mathrm{a}$, $\mathrm{b}, \mathrm{c} . .$.$) are used to denote differences (Tukey HSD tests, \mathrm{p}<0.05$ ); treatments presenting values with same letter are not significantly different. nd: not determined

\begin{tabular}{|c|c|c|c|c|c|c|}
\hline & & \multirow{2}{*}{$\begin{array}{l}\text { TLC } \\
\text { Day } 0\end{array}$} & \multicolumn{4}{|c|}{ Light regime in cylinders } \\
\hline & & & Day 3 & Day 5 & Day 3 & Day 5 \\
\hline$F_{\mathrm{v}} / F_{\mathrm{m}}$ & $\begin{array}{l}\mathrm{F} \\
-\mathrm{S} \\
-\mathrm{N}\end{array}$ & $\begin{array}{l}0.61 \pm 0.00^{\mathrm{abc}} \\
0.62 \pm 0.01^{\mathrm{bc}} \\
0.61 \pm 0.03^{\mathrm{abc}}\end{array}$ & $\begin{array}{l}0.64 \pm 0.01^{\mathrm{cdf}} \\
0.66 \pm 0.02^{\mathrm{f}} \\
0.66 \pm 0.05^{\mathrm{ef}}\end{array}$ & $\begin{array}{l}0.61 \pm 0.02^{\mathrm{abcd}} \\
0.60 \pm 0.02^{\mathrm{ab}} \\
0.66 \pm 0.03^{\mathrm{f}}\end{array}$ & $\begin{array}{l}0.62 \pm 0.01^{\mathrm{bcd}} \\
0.59 \pm 0.05^{\mathrm{ab}} \\
0.67 \pm 0.01^{\mathrm{f}}\end{array}$ & $\begin{array}{l}0.60 \pm 0.01^{\mathrm{abc}} \\
0.58 \pm 0.01^{\mathrm{a}} \\
0.65 \pm 0.01^{\text {def }}\end{array}$ \\
\hline $\mathrm{rETR}_{\max }$ & $\begin{array}{l}\mathrm{F} \\
-\mathrm{S} \\
-\mathrm{N}\end{array}$ & $\begin{array}{r}87.04 \pm 0.90^{\mathrm{bc}} \\
110.58 \pm 2.66^{\mathrm{d}} \\
116.02 \pm 6.88^{\mathrm{d}}\end{array}$ & $\begin{array}{r}109.46 \pm 13.5^{\mathrm{d}} \\
88.42 \pm 3.34^{\mathrm{bc}} \\
181.96 \pm 13.42^{\mathrm{b}}\end{array}$ & $\begin{array}{c}109.24 \pm 1.30^{\mathrm{d}} \\
84.48 \pm 0.30^{\mathrm{dc}} \\
57.12 \pm 6.70^{\mathrm{a}}\end{array}$ & $\begin{aligned} 81.50 & \pm 7.84^{\mathrm{bc}} \\
150.44 & \pm 22.60^{\mathrm{e}} \\
87.40 & \pm 15.40^{\mathrm{bc}}\end{aligned}$ & $\begin{array}{l}70.28 \pm 4.78^{\mathrm{ab}} \\
86.78 \pm 5.56^{\mathrm{bc}} \\
98.28 \pm 4.88^{\mathrm{cd}}\end{array}$ \\
\hline$\alpha_{\mathrm{ETR}}$ & $\begin{array}{l}\mathrm{F} \\
-\mathrm{S} \\
-\mathrm{N}\end{array}$ & $\begin{array}{l}0.090 \pm 0.004^{\mathrm{e}} \\
0.060 \pm 0.006^{\mathrm{abc}} \\
0.058 \pm 0.01^{\mathrm{ab}}\end{array}$ & $\begin{array}{l}0.092 \pm 0.002^{\mathrm{e}} \\
0.090 \pm 0.002^{\mathrm{e}} \\
0.050 \pm 0.002^{\mathrm{e}}\end{array}$ & $\begin{array}{l}0.066 \pm 0.004^{\mathrm{bcd}} \\
0.116 \pm 0.012^{\mathrm{f}} \\
0.058 \pm 0.002^{\mathrm{ab}}\end{array}$ & $\begin{array}{l}0.100 \pm 0.008^{\mathrm{e}} \\
0.088 \pm 0.008^{\mathrm{e}} \\
0.052 \pm 0.002^{\mathrm{a}}\end{array}$ & $\begin{array}{l}0.076 \pm 0.002^{\mathrm{d}} \\
0.124 \pm 0.006^{\mathrm{f}} \\
0.072 \pm 0.002^{\text {cd }}\end{array}$ \\
\hline$E_{\mathrm{k}}$ & $\begin{array}{l}\mathrm{F} \\
-\mathrm{S} \\
-\mathrm{N}\end{array}$ & $\begin{array}{l}169.77 \pm 6.5^{\mathrm{a}} \\
260.55 \pm 14.7^{\mathrm{bc}} \\
266.36 \pm 65.4^{\mathrm{bcd}}\end{array}$ & $\begin{array}{l}213.63 \pm 26.05^{\mathrm{bc}} \\
326.72 \pm 4.00^{\mathrm{d}} \\
149.84 \pm 18.86^{\mathrm{a}}\end{array}$ & $\begin{array}{l}215.17 \pm 20.38^{\mathrm{bc}} \\
160.93 \pm 24.52^{\mathrm{a}} \\
164.49 \pm 6.36^{\mathrm{a}}\end{array}$ & $\begin{array}{l}147.04 \pm 25.54^{\mathrm{a}} \\
185.49 \pm 77.57^{\mathrm{bc}} \\
162.97 \pm 32.49^{\mathrm{a}}\end{array}$ & $\begin{array}{l}120.68 \pm 1.79^{\mathrm{a}} \\
170.01 \pm 8.46^{\mathrm{a}} \\
116.64 \pm 15.54^{\mathrm{a}}\end{array}$ \\
\hline $\mathrm{rETR}_{\text {noon }}$ & $\begin{array}{l}\mathrm{F} \\
-\mathrm{S} \\
-\mathrm{N}\end{array}$ & nd & $\begin{array}{r}132.68 \pm 13.44^{\mathrm{b}} \\
88.82 \pm 17.48^{\mathrm{ab}} \\
61.10 \pm 11.22^{\mathrm{a}}\end{array}$ & $\begin{array}{c}99.90 \pm 14.92^{\mathrm{b}} \\
57.56 \pm 7.52^{\mathrm{a}} \\
100.84 \pm 5.58^{\mathrm{b}}\end{array}$ & $\begin{array}{l}60.74 \pm 9.70^{\mathrm{a}} \\
63.22 \pm 6.96^{\mathrm{a}} \\
68.74 \pm 14.60^{\mathrm{a}}\end{array}$ & $\begin{array}{l}89.60 \pm 19.32^{\mathrm{ab}} \\
56.78 \pm 4.42^{\mathrm{a}} \\
96.90 \pm 2.12^{\mathrm{b}}\end{array}$ \\
\hline
\end{tabular}

conditions increased when the cultures were exposed to $\mathrm{P}(\mathrm{AB}-)$ light, it decreased in $-\mathrm{S}$ and $-\mathrm{N}$ treatments. On the contrary, $\mathrm{rETR}_{\max }$ did not vary after $5 \mathrm{~d}$ in PAB conditions, although a peak was observed after $3 \mathrm{~d}$ in $-\mathrm{S}$ cultures. By the end of the experiment, cultures under $\mathrm{F}$ conditions showed the highest values under $\mathrm{P}(\mathrm{AB}-)$ light, whereas the lowest values were reached in $-\mathrm{N}$ treatment. The opposite was observed in PAB conditions, where the highest values corresponded to $-\mathrm{N}$ cultures and the lowest values were observed in full nutrient conditions.

Photosynthetic efficiency $\left(\alpha_{\text {ETR }}\right)$ was affected by the initial nutrient conditions; the $\mathrm{F}$ treatment presented higher efficiency than the nutrient-deprived ones (Table 2). After being transferred to cylinders for $5 \mathrm{~d}$, efficiency in the $-\mathrm{S}$ treatment was significantly higher than in the others regardless of the light conditions, whereas in the F treatment efficiency was reduced. In contrast, PAB light conditions caused an increase over time in efficiency in the $-\mathrm{N}$ treatment.

Saturated irradiance $\left(E_{\mathrm{k}}\right)$ from the RLCs decreased after $5 \mathrm{~d}$ in both $-\mathrm{S}$ and $-\mathrm{N}$ cultures, irrespective of light regime. However, in full nutrient conditions, $E_{\mathrm{k}}$ increased in $\mathrm{P}(\mathrm{AB}-)$, whereas it did not vary under $\mathrm{PAB}$. By the end of the experiment, $E_{\mathrm{k}}$ did not show significant differences between treatments, except cultures under full nutrient and $\mathrm{P}(\mathrm{AB}-)$ conditions, which showed the highest values.

Under outdoor conditions, after $3 \mathrm{~d}$, the photon fluence of PAR followed a similar daily cycle with maximum values at midday in all cases (Fig. 4). Daily maximal values were higher in $\mathrm{F}$ and $-\mathrm{N}$ than in $-\mathrm{S}$ cultures under both light regimes. Common daily $\Delta F / F_{\mathrm{m}}{ }^{\prime}$ cycles with midday decrease were observed on Day 3 in $\mathrm{P}(\mathrm{AB}-)$ conditions. After $5 \mathrm{~d}$ under these light conditions and throughout the whole experimental period, such a decrease was not observed in PAB treatments, except for cultures in full nutrient conditions. In situ rETR reached a peak at midday in all cases. Maximal values tended to decrease in $\mathrm{P}(\mathrm{AB}-)$ treatments, except for in $-\mathrm{N}$ cultures, whereas an increasing trend was observed during the experiment under PAB light conditions.

\section{Biochemical composition}

The elemental composition expressed as \% of C, $\mathrm{N}$ and $\mathrm{S}$ varied depending on the treatment and the day of the experiment (Table 3). At Day 0, F cultures presented the highest content of $\mathrm{C}, \mathrm{N}$ and $\mathrm{S}$, whereas the 

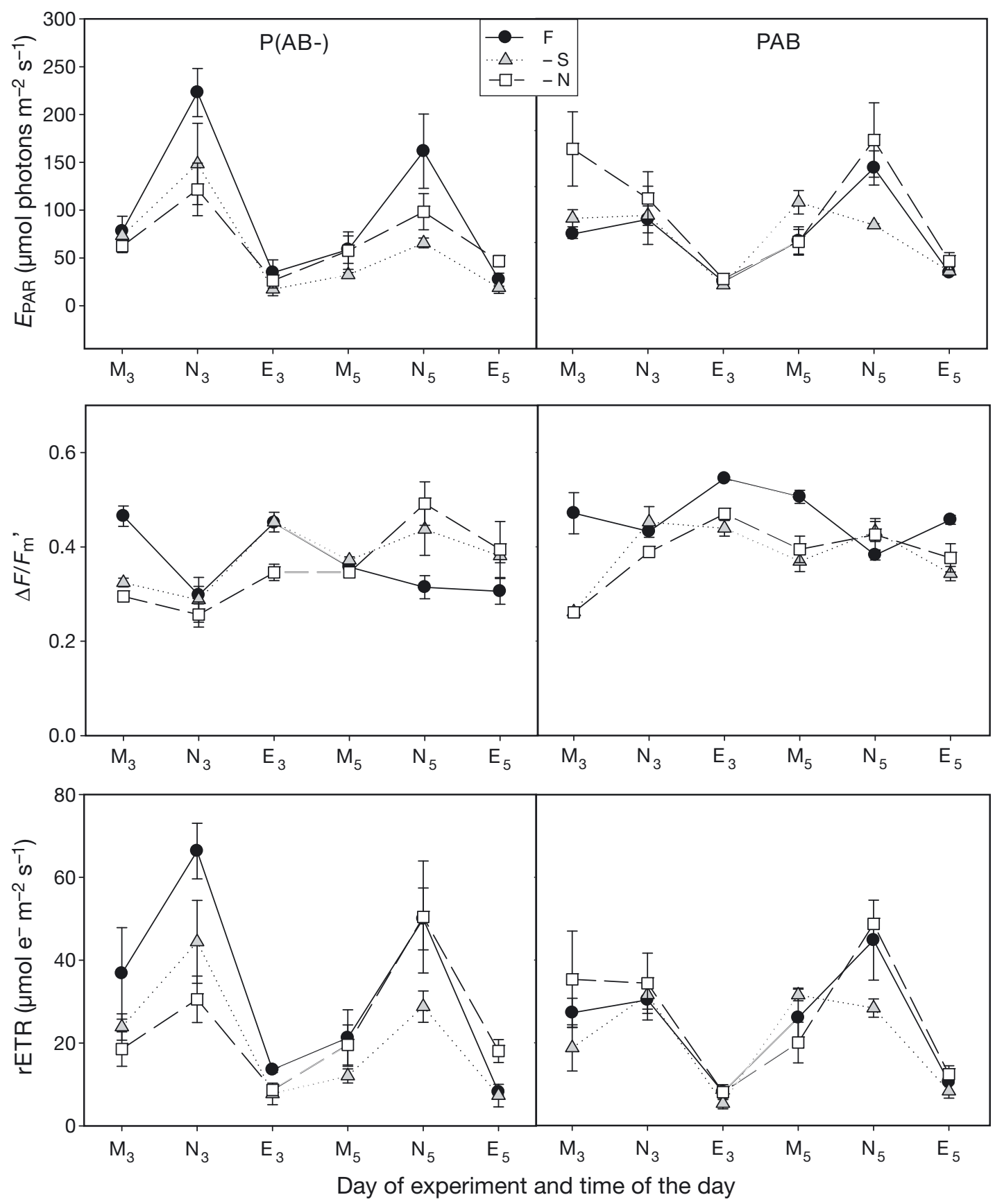

Fig. 4. Photon fluence rate of PAR ( $\left.E_{\mathrm{PAR}}\right)$, effective quantum yield of PSII ( $\left.\Delta F / F_{\mathrm{m}}{ }^{\prime}\right)$ and relative electron transport rate ( $\mathrm{rETR}$ ) in the morning $(\mathrm{M})$, noon $(\mathrm{N})$ and evening $(\mathrm{E})$ for 2 different days during the experimental period of culture in methacrylate cylindrical vessels: Day 3 (21 September 2012) and Day 5 (23 September 2012) for the different nutrient treatments, F: full nutrients; $-\mathrm{N}$ : nitrogen limited; $-\mathrm{S}$ : sulphur limited; and light treatments, including full solar radiation (PAB) or the same PAR but decreased UVR $(\mathrm{P}(\mathrm{AB}-))$

$-\mathrm{N}$ treatment had the lowest, and $-\mathrm{S}$ cultures showed intermediate values for all components. At Day 5, PAB F treatment presented the highest $\mathrm{C}$ content, whereas $-\mathrm{S}$ had the lowest. The other treatments showed intermediate values that were not statistically different (Table 1). PAB F and $\mathrm{P}(\mathrm{AB}-$ ) $-\mathrm{N}$ treatments presented the highest $\mathrm{N}$ content, whereas PAB -S presented the lowest, with the remaining treatments presenting intermediate values, although not significantly different from the highest and lowest ones. The $\mathrm{S}$ content was slightly affected by all nutrient conditions, with $-\mathrm{N}$ presenting the highest 
content. A general trend of increasing content of $\mathrm{C}, \mathrm{N}$ and $\mathrm{S}$ occurred over time for the $-\mathrm{N}$ treatment, while they decreased or remained the same in F cultures. Along the time course, the $-\mathrm{S}$ treatment was more affected by light conditions such that $\mathrm{C}$ and $\mathrm{N}$ decreased in the $\mathrm{PAB}-\mathrm{S}$ treatment, while $\mathrm{C}$ increased in $\mathrm{P}(\mathrm{AB}-)-\mathrm{S}_{\text {; the }} \mathrm{S}$ content showed a slight increase in both light conditions.

The nutrient conditions prevailing in the outdoor TLC caused differences in protein content in the vessels at Day 0: -S presented the highest protein content, $\mathrm{F}$ the lowest, and $-\mathrm{N}$ showed intermediate values, although no statistical differences were found between these initial values. However, after $5 \mathrm{~d}$ of culture in the cylinders, these differences disappeared, and all treatments presented similar protein content, regardless of the nutrient and/or light condition. It should be noted that the final protein content was nearly double the initial one. Day 3, not shown, presented intermediate values between Day 0 and 5 (Table 3).

Lipid content (\% of dry wt) for the different light and nutrient depletion treatments are presented in Fig. 5. $\mathrm{N}$ deprivation in the outdoor TLC resulted in higher lipid content. After $3 \mathrm{~d}$ of culture in the cylinders, the lipid content increased in all samples. The

Table 3. Total internal $\mathrm{C}, \mathrm{N}$ and $\mathrm{S}$ expressed as percentage (\% of dry wt) and soluble protein content (SP, $\mu \mathrm{g} \mathrm{mg}^{-1} \mathrm{dry} \mathrm{wt}$ biomass) from Day 0 (inocula from thin-layer cascade, so no replicates are available, except for SP analysis) and after $5 \mathrm{~d}$ in vessels (Day 5) $(\mathrm{n}=3)$. Two-way (treatment $\times$ light) or 3 way (treatment $\times$ light $\times$ time) ANOVAs were performed depending on the availability of samples and replicates. If required, a letter $(\mathrm{a}, \mathrm{b}, \mathrm{c} . .$.$) is used to denote differences (HSD$ tests, $\mathrm{p}<0.05)$; treatments presenting values with the same letter are not significantly different. F: full nutrients; $-\mathrm{S}(-\mathrm{N})$ : sulphur (nitrogen) starvation

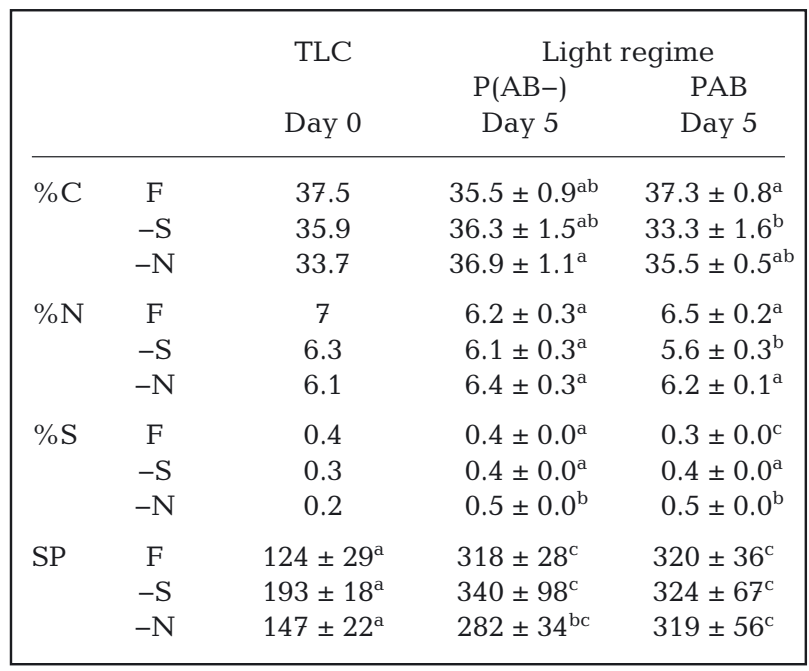

greatest increase of lipids was observed in those cylinders combining reduced UVR and nutrient depletion: $\mathrm{P}(\mathrm{AB}-)-\mathrm{S}$ and $\mathrm{P}(\mathrm{AB}-)-\mathrm{N}$. Of particular interest is the case of $-\mathrm{N}$, with values around $35 \%$. Lipid content reached its lowest values in the $\mathrm{F}$ treatment. After $5 \mathrm{~d}$, light conditions continued affecting the lipid content, with cultures exposed to PAB presenting the highest percentages of lipids. Both $\mathrm{F}$ and $\mathrm{PAB}-\mathrm{S}$ conditions increased the lipid content compared to Day 3. Accordingly, $\mathrm{P}(\mathrm{AB}-)-\mathrm{S}$ and $-\mathrm{N}$ presented the lowest lipid content, although these treatments showed the highest lipid percentage at Day 3.

\section{Lipid peroxidation}

After $5 \mathrm{~d}$ in cylinders, all algal cultures, with the exception of controls (full nutrients), showed a doubling of TBARS content (Fig. 6). Both nutrient conditions $(p<0.01)$ and time $(p<0.001)$ caused changes in lipid peroxidation (TBARS per cell). The TBARS concentration shown a time-related increase, and both $-\mathrm{S}$ and $-\mathrm{N}$ resulted in greater increases of TBARS compared to the full nutrient condition. Nutrient limitation, even when the cultures were exposed to a lower UVR intensity, was enough to significantly increase TBARS per cell $(101 \%$ and $168 \%$, respectively). The synergistic effect of nutrient limitation and UVR increased the TBARS content, especially in the case of the $-\mathrm{N}$ cultures (34 and $18 \%$ for $-\mathrm{N}$ and $-\mathrm{S}$, respectively).

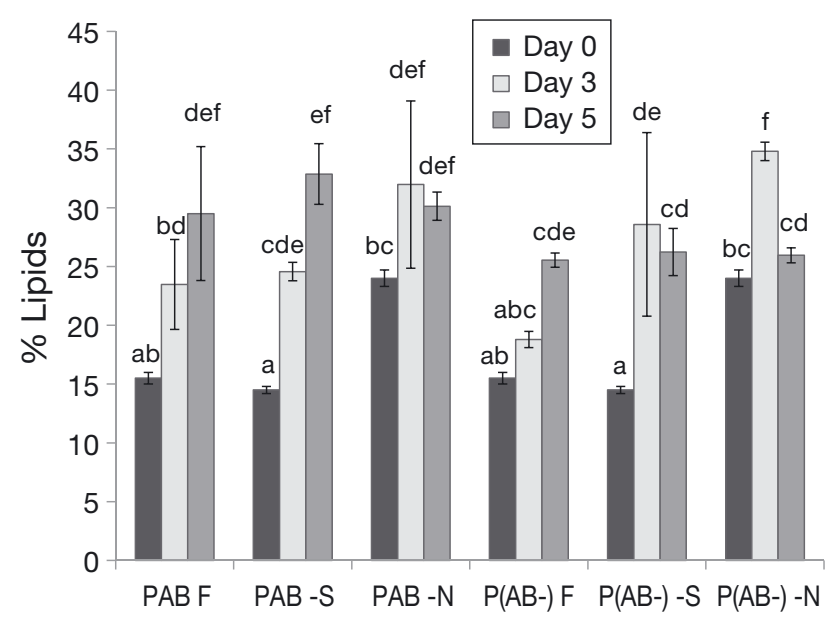

Fig. 5. Lipid content (\% of dry wt) in the different nutrient and light treatments (see Fig. 1) at the initial time (algae just transferred from TLC, Day 0), on Day 3 (21 September 2012), and on Day 5 (23 September 2012). Columns showing different letters indicate that differences are statistically significant $(p<0.05)$, whereas the use of the same letter indicates no differences 


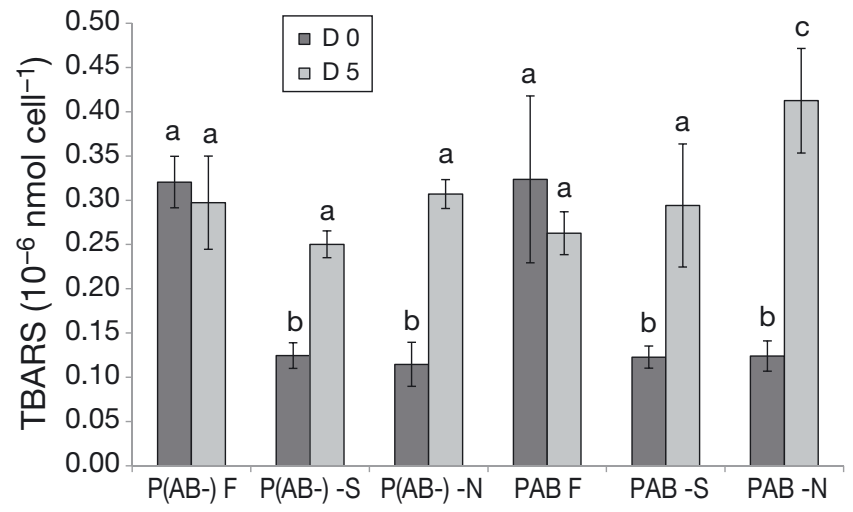

Fig. 6. Lipid peroxidation expressed as nmol MDA equivalent by total cell number in the different nutrient and light treatments (see Fig. 1) at the initial time (algae just transferred from TLC; Day 0) and on Day 5, the last day of the experiment (23 September 2012). Columns showing different letters indicate that differences are statistically significant ( $\mathrm{p}$ $<0.05$ ), whereas the use of the same letter indicates no difference. TBARS: thiobarbituric acid reactive substances

\section{Correlation analysis}

As expected, both $K_{\mathrm{c}, \mathrm{UVR}}$ and $K_{\mathrm{c}, \mathrm{PAR}}$ were negatively correlated with pigments and cell numbers, whereas a positive correlation was found with proteins and lipids (Table 4). Pigments were positively correlated with cell density. In contrast, cell density was negatively correlated with $\mathrm{rETR}_{\text {noon }}$ (rETR measured in situ at 13:00 h) and with internal compounds, such as proteins and lipids, as well as percentages of $\mathrm{C}, \mathrm{N}$, and $\mathrm{S}$. The $\mathrm{rETR}_{\text {noon }}$ and $\mathrm{rETR}_{\max }$ (obtained from RLCs) were positively correlated with other RLC parameters, i.e. $\alpha_{\mathrm{ETR}}$ and $E_{\mathrm{k}}$, and also with the UV index. Proteins and lipids were positively correlated, both presenting a negative correlation with pigments. The rest of the analyzed internal compounds, i.e. C, N, S were positively correlated.

\section{DISCUSSION}

Initially, cell cultures were grown in TLC to acclimate to the nutrient conditions ( $\mathrm{N}$ and $\mathrm{S}$ deprivation) under complete sunlight (including UVA and UVB). In the TLC, approximately two-thirds of the time, the cells were under dark conditions (due to the pipes and tank of the TLC system), whereas once they were transferred to cylinders, algae were exposed to different light conditions both in quality and quantity (see Jerez et al. 2014). This difference may explain some of the changes during the first moments of the culture in cylinders. The stationary bottle incubation technique for estimating rates of primary productivity has mainly been criticized because of 'bottle effects' related to the elimination of natural turbulence and the presence of photoinhibition. However, these growing conditions have 2 separate, but synergistic, effects. On the one hand, phytoplankton cells move through a light/dark cycle. On the other hand, the boundary layer decreases, which increases the rate of exchange of nutrients and metabolites through the cell wall. Hence, more nutrients are available, and light could be utilized more efficiently, resulting in increased productivity (Grobbelaar 1989). In our study, vigorous aeration was applied to achieve greater hydrodynamics in the culture.

Algae under PAB showed photosynthetic parameters similar to the sun-type pattern, i.e. algae acclimated to high irradiances presented high capacity for energy dissipation and photoprotection (Krause \& Jahns 2004). Accordingly, these algae presented an increase of $\mathrm{rETR}_{\max }$ and $E_{\mathrm{k}}$ but a slight decrease of $\alpha_{\mathrm{ETR}}$, as observed under $\mathrm{F}$ nutrient conditions on Day 3. The ETR max $_{\text {ax }}$ was higher on Day 3 under $-\mathrm{S}$ and $\mathrm{PAB}$ compared to $\mathrm{P}(\mathrm{AB}-)$, but $E_{\mathrm{k}}$ decreased without any variation in $\alpha_{\mathrm{ETR}}$ i no differences were observed after $5 \mathrm{~d}$ of culture. However, under $-\mathrm{N}$, no differences in the photosynthetic parameters were observed on Day 3, whereas after 5 d, rETR $\max$ was higher under $\mathrm{PAB}$ than $\mathrm{P}(\mathrm{AB}-)$, although $E_{\mathrm{k}}$ and $\alpha_{\mathrm{ETR}}$ were not significantly different (Table 2). Higher photosynthetic capacity and recovery after damage under $\mathrm{PAB}$ compared to $\mathrm{P}(\mathrm{AB}-)$ has been previously reported in algae growing under high natural solar irradiance (Flores-Moya et al. 1999, Helbling et al. 2003, Hanelt et al. 2006).

The depletion of nutrients influences many biochemical processes, such as nutrient uptake, pigment synthesis, photosynthesis, cellular growth and organism composition (Dean et al. 2010). The level of proteins in cultures was higher in all nutrient treatments in cylinders than in those under TLCs, even though the total internal $\mathrm{N}$ content was similar in the 2 culture systems. No differences in the level of proteins were found due to nutrient treatments. In contrast, the content of chlorophyll and carotenoids was reduced under nutrient-deprived treatments on Day 1. As reported by Young \& Beardall (2003), photosynthetic capacity and, consequently, pigment content decrease in microalgae under limitation of N. Overall, pigment concentration was heavily impacted by the $\mathrm{N}$ concentration of the medium ( $\mathrm{Li}$ et al. 2008, I. Malpartida et al. unpubl. data). Moreover, since chlorophyll is a N-rich compound, it can be used as an internal supply of $\mathrm{N}$ for algae metabolism (Smart 


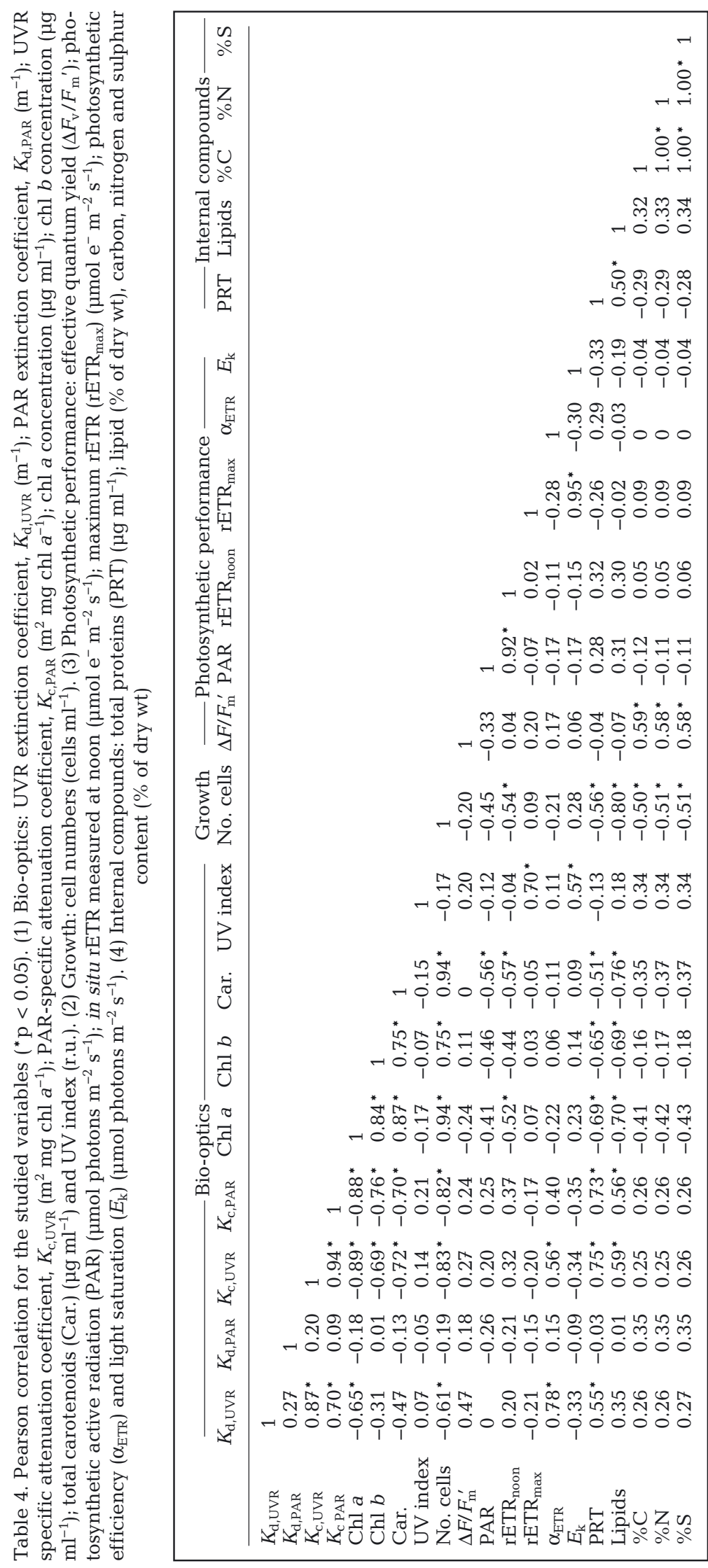

1994, Díaz et al. 2006). After 5 d, all treatments showed a decrease in pigment contents. Niyogi et al. (1997) described how promotion of the production of carotenoids allows adaptation to possible photo-oxidation when irradiance decreases the synthesis of chlorophyll structures. Low $\mathrm{N}$ nutrition reduces the levels of chlorophyll and soluble proteins, such as RUBISCO, in different algae (Beardall 1991, Wulff et al. 2000). Biliprotein contents decreased in both cyanobacteria (Boussiba \& Richmond 1979, Schenk et al. 1983) and red algae (Talarico \& Maranzana 2000); in contrast, high nutrient supply produced a rapid increase in phycobiliproteins, reaching about 30 to $40 \%$ of the soluble proteins in cyanobacteria (Tandeau de Marsac \& Houmardd 1993). Our results show a decrease in chlorophyll but not an increase in carotenoids content, which was very low. This pattern can be explained by the possible cellular acclimation to photo-oxidation of pigments under high irradiance, as suggested by Rosales-Loaiza et al. (2008). In fact, these cultures were first acclimated to complete sunlight, as they were cultivated in TLCs.

Because of the potential commercial interest in lipids, lipid accumulation was carefully assessed. The variation in biomass productivity provoked by treatments affected the biochemical composition of the cultures, showing a clear bioaccumulation of lipids under starvation conditions ( $-\mathrm{S}$ and $-\mathrm{N}$ treatments). Lipid metabolism is a good example of the synergistic effect of nutrients and UVR, showing 2 differentiated stages. That is, during the first $3 \mathrm{~d}$, the nutrient condition factor controlled the accumulation of lipids, while during the last $2 \mathrm{~d}$, light was the controlling factor. After $3 \mathrm{~d}$ in cylinders, the $-\mathrm{N}$ treatment, irrespective of light conditions, showed the highest lipid content, reaching nearly $35 \%$ of dry wt. At the same time, the low ETR data indicated that this increase was realized under low-production conditions, in agreement with other studies (Illman et al. 2000, Yeh \& Chang 2012). In other studies, the addition of $\mathrm{N}$ and Fe increased the lipid production in Dunaliella salina based on the increase of biomass productivity (Mata et al. 2013). In our case, the decrease in the cell number by $\mathrm{N}$ limitation was 
not compensated by the increase of lipid content per cell, as in the case of $-\mathrm{S}$ cultures. This effect may have been a response to nutrient stress; the responses to stress may include a decrease of cellular growth along with the simultaneous increase of energy storage molecules (Meng et al. 2009).

The UVR effects presented a strong time dependency, suggesting the importance of the UVR dose accumulated by the algae. After $5 \mathrm{~d}$, cultures under $\mathrm{PAB}$ presented the greatest lipid content. Particularly, $-\mathrm{S}$ showed the greatest enhancement in lipid production, possibly because microalgal requirements of $\mathrm{S}$ are quite low, between 0.15 and $1.96 \%$ (Barsanti \& Gualtieri 2006). S deficiency provoked a significantly higher $\mathrm{pH}$ in the algal culture, with values around 7.8 to 8.0 . The $\mathrm{pH}$ increase was significantly enhanced by UVR. Kosourov et al. (2003) reported that $\mathrm{S}$ deprivation of cultures of Chlamydomonas reinhardtii resulted in the photoproduction of $\mathrm{H}_{2}$, which could alter $\mathrm{pH}$ equilibrium. However, a significant change in $\mathrm{CO}_{2}$ availability is not expected due to $\mathrm{pH}$ differences among treatments (in the range of $\mathrm{pH}$ shown, most of the $\mathrm{C}$ is available as $\mathrm{HCO}_{3}{ }^{-}$). Several studies have shown that negative effects on productivity of marine or freshwater planktonic algae appear only at pH > 8.8 (Azov 1982, Chen \& Durbin 1994).

The effect of UVR depends on maintaining a dynamic equilibrium between damage and repair (Lesser et al. 1994, Heraud \& Beardall 2000, Litchman et al. 2002). Any imbalance in these processes affects PSII dynamics and leads to photoinhibition. The decrease in chlorophyll fluorescence under UVR was related to the decrease in pigment content observed under both of the light treatments. The fluorescence decrease was probably also related to damage to PSII (see review by Vincent \& Neale 2000). Over both short and long terms, Carrillo et al. (2008) showed the lack of harmful UVR effects on primary production, chl $a$ and biomass, suggesting that the loss of C, which results in low sestonic $\mathrm{C}: \mathrm{P}$ ratios, might be part of an adaptive strategy of phytoplankton to high UVR and extreme nutrient limitation. It is also known that nutrient enrichment $(\mathrm{P})$ may reduce the negative effect of UVB radiation on the growth of other microalgae (Germ et al. 2002).

High PAR irradiance can also provoke photoinhibition (Villafañe et al. 2003). In our study, PAR irradiance was the same under both light treatments, and in $\mathrm{P}(\mathrm{AB}-)$, both UVA and UVB were decreased by the cut-off filter used. UVA has been reported to have both negative and positive effects in phytoplankton. A decrease in primary production (mea- sured as $\mathrm{C}$ incorporation) is among the negative effects (Villafañe et al. 2003), while among the positive effects, UVA can act to enhance C fixation (Helbling et al. 2003), allow photorepair (Buma et al. 2003), increase biomass (Wu et al. 2005) and favour primary productivity by means of utilization of UVA as an energy supply for $\mathrm{CO}_{2}$ fixation (Gao et al. 2007). The impact of UVR on the cells depends on the bio-optical characteristics related to cell size and pigment composition (Figueroa et al. 1997).

Evidence of photoacclimation can also be seen in our study. Chlorella fusca is a relatively large species, and therefore, it is expected to present higher resistance to UVR than species with smaller cells. The increase in cell size diminishes UVB penetration in the nucleus and chloroplasts, reducing the potential damage to DNA and photosystems. It is commonly accepted that small cells (nanoplankton) are more vulnerable to UVR than large cells (microplankton) because the latter have slower kinetics of photoinhibition and can therefore resist greater UVR-related damage to photosynthesis (Figueroa et al. 1997, Villafañe et al. 2003). In this study, both $K_{\mathrm{c}, \mathrm{PAR}}$ and $K_{\mathrm{c}, \mathrm{UVR}}$ were correlated with photosynthetic efficiency $\left(\alpha_{\text {ЕTR }}\right)$ but not with photosynthetic capacity (rETR). Figueroa et al. (1997) showed that a specific attenuation coefficient $\left(K_{\mathrm{c}}\right)$ ranging from 0.01 to $0.03 \mathrm{~m}^{2} \mathrm{mg}^{-1} \mathrm{chl}$ a explained the acclimation to increased irradiance, demonstrating that increases of $K_{\mathrm{c}}$ were related to increased photoinhibition. In our experiment, $K_{\mathrm{C}, \text { UVR }}$ showed the highest values for PAB F and $-\mathrm{N}$, which is consistent because UVR was complete in these treatments, allowing for a certain level of photoinhibition. In the case of $-\mathrm{S}$, the value is higher in $\mathrm{P}(\mathrm{AB}-)$ conditions but still close to the value in $\mathrm{PAB}$. It is possible that $\mathrm{PAB}$ conditions provoked more damage and less recovery in cells and that this effect was also important for the $-\mathrm{S}$ treatment after $5 \mathrm{~d}$, even under lower UVR conditions.

Finally, the UVR effect on lipids was determined because UVR is a known source of reactive oxygen species, which increase oxidative stress in photosynthetic organisms (Lesser et al. 1994, Foyer \& Shigeoka 2011). However, oxidative stress may also be increased if the antioxidant mechanisms of cells are stopped or diminished. One of the consequences of oxidative stress is lipid peroxidation, as a result of the oxidation of unsaturated lipids; this process has been reported in most algal groups (Malanga \& Puntarulo 1995, Lesser 1996, Malanga et al. 1997, Rijstenbil 2001, 2002). However, it is noteworthy that lipid peroxidation did not happen in the full nutrient treatment, which can be attributed to the full effec- 
tiveness of repair mechanisms that had no limitation from nutrient availability. Nutrient limitation is known to induce ROS production and decrease the repair capability of a cell (Berges \& Falkowski 1998, Logan et al. 1999, Bucciarelli \& Sunda 2003, Menon et al. 2013). Here, the combined effect of limitation of essential nutrients like $\mathrm{N}$ and $\mathrm{S}$ needed for oxidative repair mechanisms under $\mathrm{PAB}$ conditions resulted in increased lipid peroxidation (Lesser et al. 1994, Litchman et al. 2002, Van De Poll et al. 2005).

Based on appropriate control of the nutrient and light growing conditions, our data showed that it would be feasible to control productivity, growth and UVR acclimation of Chlorella fusca cultures. These processes would lead to changes in the biochemical composition of the algal cells, which may result in the bioaccumulation of molecules at rates that make its commercial exploitation feasible.

Acknowledgements. We acknowledge the financial and technical (use of PAM fluorometers) support by Walz to the GAP 9 Workshop 'Influence of the pulsed-supply of nitrogen on primary productivity in phytoplankton and marine macrophytes: an experimental approach'. We also thank Redox, the University of Málaga, Ministry of Economy and Competitiveness of Spanish Government (Acción Complementaria CTM2011-15659-E) and the Spanish Institute of Oceanography. The participation of E.N. was also supported by the Spanish Ministry of Economy and Competitiveness of Spanish Government (Ref. BFU2010-22053).

\section{LITERATURE CITED}

Acién Fernández FG, González-López CV, Fernández Sevilla JM, Molina Grima E (2012) Conversion of $\mathrm{CO}_{2}$ into biomass by microalgae: How realistic a contribution may it be to significant $\mathrm{CO}_{2}$ removal? Appl Microbiol Biotechnol 96:577-586

Adarme-Vega TC, Lim DKY, Timmins M, Vernen F, Li Y, Schenk PM (2012) Microalgal biofactories: a promising approach towards sustainable omega-3 fatty acid production. Microb Cell Fact 11:96

Aphalo PJ, Albert A, Mcleod AR, Robson TM, Rosenqvist E (eds) (2012) Beyond the visible. A handbook of best practice in plant UV photobiology. University of Helsinki

- Azov Y (1982) Effect of pH on inorganic carbon uptake in algal cultures inorganic carbon uptake in algal cultures. Appl Environ Microbiol 43:1300-1306

Barbieri ES, Villafañe VE, Helbling EW (2002) Experimental assessment of UV effects on temperate marine phytoplankton when exposed to variable radiation regimes. Limnol Oceanogr 47:1648-1655

Barsanti L, Gualtieri P (2006) Algae: anatomy, biochemistry and biotechnology. Taylor \& Francis, Boca Raton, FL

Beardall J (1991) Effects of photon flux density on the ' $\mathrm{CO}_{2}$-concentrating mechanism' of the cyanobacterium Anabaena variabilis. J Plankton Res 13:133-141

Beardall J, Raven JA (2004) The potential effects of global climate change on microalgal photosynthesis, growth and ecology. Phycologia 43:26-40
Berges JA, Falkowski PG (1998) Physiological stress and cell death in marine phytoplankton: induction of proteases in response to nitrogen or light limitation. Limnol Oceanogr 43:129-135

> Berges JA, Charlebois DO, Mauzerall DC, Falkowski PG (1996) Differential effects of nitrogen limitation on photosynthetic efficiency of photosystems I and II in microalgae. Plant Physiol 110:689-696

Bouchard JN, Longhi ML, Roy S, Campbell DA, Ferreyra G (2008) Interaction of nitrogen status and UVB sensitivity in a temperate phytoplankton assemblage. J Exp Mar Biol Ecol 359:67-76

Boussiba S, Richmond A (1979) Isolation and characterization of phycocyanins from the blue-green alga Spirulina platensis. Arch Microbiol 120:155-159

Bradford MM (1976) A rapid and sensitive method for the quantitation of microgram quantities of protein utilizing the principle of protein-dye binding. Anal Biochem 72: 248-254

Bucciarelli E, Sunda WG (2003) Influence of $\mathrm{CO}_{2}$, nitrate, phosphate, and silicate limitation on intracellular dimethylsulfoniopropionate in batch cultures of the coastal diatom Thalassiosira pseudonana. Limnol Oceanogr 48: 2256-2264

Buma AGJ, Zemmelink HJ, Sjollema K, Gieskes WWC (1996) UVB radiation modifies protein and photosynthetic pigment content, volume and ultrastructure of marine diatoms. Mar Ecol Prog Ser 142:47-54

Buma AGJ, Boelen P, Jeffrey WA (2003) UVR-induced DNA damage in aquatic organisms. In: Helbling W, Zagarese $\mathrm{H}$ (eds) Comprehensive series in photosciences: UV effects in aquatic organisms and ecosystems. Royal Society of Chemistry, Cambridge

Cabrera S, Lopez M, Tartarotti B (1997) Phytoplankton and zooplankton response to ultraviolet radiation in a highaltitude Andean lake: short- versus long-term effects. J Plankton Res 19:1565-1582

Carrillo P, Delgado-Molina JA, Medina-Sánchez JM, Bullejos FJ, Villar-Argaiz M (2008) Phosphorus inputs unmask negative effects of ultraviolet radiation on algae in a high mountain lake. Glob Change Biol 14:423-439

Chen CY, Durbin EG (1994) Effects of pH on the growth and carbon uptake of marine phytoplankton. Mar Ecol Prog Ser 109:83-94

> Cockell CS, Knowland J (1999) Ultraviolet radiation screening compounds. Biol Rev Camb Philos Soc 74:311-345

De Pauw N, Persoone G (1988) Microalgae for aquaculture. In: Borowitzka MA, Borowitzka LJ (eds) Microalgal biotechnology. Cambridge University Press, Cambridge, p 197-221

> Dean AP, Sigee DC, Estrada B, Pittman JK (2010) Using FTIR spectroscopy for rapid determination of lipid accumulation in response to nitrogen limitation in freshwater microalgae. Bioresour Technol 101:4499-4507

- Demmig-Adams B, Adams WW (1996) The role of xanthophyll cycle carotenoids in the protection of photosynthesis. Trends Plant Sci 1:21-26

Díaz C, Saliba-Colombani V, Loudet O, Belluomo P and others (2006) Leaf yellowing and anthocyanin accumulation are two genetically independent strategies in response to nitrogen limitation in Arabidopsis thaliana. Plant Cell Physiol 47:74-83

Eilers PHC, Peeters JCH (1988) A model for the relationship between light intensity and the rate of photosynthesis in phytoplankton. Ecol Modell 42:199-215 
Figueroa F, Mercado J, Jiménez C, Salles S and others (1997) Relationship between bio-optical characteristics and photoinhibition of phytoplankton. Aquat Bot 59:237-251

Figueroa FL, Santos R, Conde-Álvarez R, Mata L and others (2006) The use of chlorophyll fluorescence for monitoring photosynthetic condition of two tank-cultivated red macroalgae using fishpond effluents. Bot Mar 49:275-282

> Figueroa FL, Bueno A, Korbee N, Santos R, Mata L, Schuenhoff A (2008) Accumulation of mycosporine-like amino acids in Asparagopsis armata grown in tanks with fishpond effluents of gilthead sea bream, Asparus aurata. J World Aquacult Soc 39:692-699

> Figueroa FL, Jerez CG, Korbee N (2013) Use of in vivo chlorophyll fluorescence to estimate photosynthetic activity and biomass productivity in microalgae grown in different culture systems. Lat Am J Aquat Res 41: 801-819

Flores-Moya A, Hanelt D, Figueroa FL, Altamirano M, Viñegla B, Salles S (1999) Involvement of solar UV-B radiation in recovery of inhibited photsynthesis in the brown alga Dictyota dichotoma (Hudson) Lamouroux. J Photochem Photobiol B 49:129-135

- Foyer CH, Shigeoka S (2011) Understanding oxidative stress and antioxidant functions to enhance photosynthesis. Plant Physiol 155:93-100

> Gao K, Wu Y, Li G, Wu H, Villafañe VE, Helbling EW (2007) Solar UV radiation drives $\mathrm{CO}_{2}$ fixation in marine phytoplankton: a double-edged sword. Plant Physiol 144: 54-59

Geider RJ, MacIntyre HL, Graziano LM, McKay RML (1998) Responses of the photosynthetic apparatus of Dunaliella tertiolecta (Chlorophyceae) to nitrogen and phosphorus limitation. Eur J Phycol 33:315-332

Genty B, Briantais JM, Baker NR (1989) The relationship between the quantum yield of photosynthetic electrontransport and quenching of chlorophyll fluorescence. Biochim Biophys Acta 990:87-92

Germ M, Drmaz D, Sisko M, Gaberscik A (2002) Effects of UV-B radiation on green alga Scenedesmus quadricauda: growth rate, UV-B absorbing compounds and potential respiration in phosphorus rich and phosphorus poor medium. Phyton (Horn) 42:25-37

Goiris K, Muylaert K, Fraeye I, Foubert I and others (2012) Antioxidant potential of microalgae in relation to their phenolic and carotenoid content. J Appl Phycol 24: 1477-1486

Golaszewski J, Upadhyaya MK (2003) The effect of UV-B radiation on plant growth and development. Plant Soil Environ 49:135-140

Grobbelaar JU (1989) Do light/dark cycles of medium frequency enhance phytoplankton productivity? J Appl Phycol 1:333-340

Grossman A, Takahashi H (2001) Macronutrient utilization by photosynthetic eukaryotes and the fabric of interactions. Annu Rev Plant Physiol Plant Mol Biol 52:163-210

> Häder DP, Figueroa FL (1997) Photoecophysiology of marine macroalgae. Photochem Photobiol 66:1-14

> Hanelt D, Hawes I, Rae R (2006) Reduction of UV-B radiation causes an enhancement of photoinhibition in high light stressed aquatic plants from New Zealand lakes. J Photochem Photobiol B 84:89-102

Hase E, Otsuka H, Mihara S, Tamiya H (1959) Role of sulfur in the cell division of Chlorella, studied by the technique of synchronous culture. Biochim Biophys Acta 35: 180-189
Heath RL, Packer L (1968) Photoperoxidation in isolated chloroplasts. I. Kinetics and stoichiometry of fatty acid peroxidation. Arch Biochem Biophys 125:189-198

Hegglin MI, Shepherd TG (2009) Large climate-induced changes in ultraviolet index and stratosphere-totroposphere ozone flux. Nat Geosci 2:687-691

> Helbling E, Gao K, Gonçalves R, Wu H, Villafañe V (2003) Utilization of solar UV radiation by coastal phytoplankton assemblages off SE China when exposed to fast mixing. Mar Ecol Prog Ser 259:59-66

Helbling EW, Gao K, Ai H, Ma Z, Villafañe VE (2006) Differential responses of Nostoc sphaeroides and Arthrospira platensis to solar ultraviolet radiation exposure. J Appl Phycol 18:57-66

> Heraud P, Beardall J (2000) Changes in chlorophyll fluorescence during exposure of Dunaliella tertiolecta to UV radiation indicate a dynamic interaction between damage and repair processes. Photosynth Res 63:123-134

Høiskar BAK, Haugen R, Danielsen T, Kylling A and others (2003) Multichannel moderate-bandwidth filter instrument for measurement of the ozone-column amount, cloud transmittance, and ultraviolet dose rates. Appl Opt 42:3472-3479

Illman AM, Scragg AH, Shales SW (2000) Increase in Chlorella strains calorific values when grown in low nitrogen medium. Enzyme Microb Technol 27:631-635

Izard J, Limberger RJ (2003) Rapid screening method for quantitation of bacterial cell lipids from whole cells. J Microbiol Methods 55:411-418

Jerez CG, Navarro E, Malpartida I, Rico RM, Masojídek J, Abdala R, Figueroa FL (2014) Hydrodynamics and photosynthesis performance of Chlorella fusca grown in a thinlayer cascade (TLC) system. Aquat Biol 22:111-122

Karentz D, Cleaver JE, Mitchell DL (1991) Cell-survival characteristics and molecular responses of antarctic phytoplankton to ultraviolet-B radiation. J Phycol 27: 326-341

Kasai F, Arts MT (1998) The interactive effects of UV-B radiation and a herbicide on uptake and allocation of carbon in two strains of the green alga Scenedesmus. Aquat Ecol 31:261-272

> Knight JA, Anderson S, Rawle JM (1972) Chemical basis of the sulfo-phospho-vanillin reaction for estimating total serum lipids. Clin Chem 18:199-202

> Kolber Z, Zehr J, Falkowski P (1988) Effects of growth irradiance and nitrogen limitation on photosynthetic energy conversion in photosystem II. Plant Physiol 88: 923-929

Korbee N, Mata MT, Figueroa FL (2010) Photoprotection mechanisms against ultraviolet radiation in Heterocapsa sp. (Dinophyceae) are influenced by nitrogen availability: mycosporine-like amino acids vs. xanthophyll cycle. Limnol Oceanogr 55:899-908

Kosourov S, Seibert M, Ghirardi ML (2003) Effects of extracellular $\mathrm{pH}$ on the metabolic pathways in sulfurdeprived, $\mathrm{H}_{2}$-producing Chlamydomonas reinhardtii cultures. Plant Cell Physiol 44:146-155

Krause GH, Jahns P (2004) Non-photochemical energy dissipation determined by chlorophyll fluorescence quenching: characterization and function. In: Papageorgiou G, Govindjee (eds) Chlorophyll a fluorescence: a signature of photosynthesis. Springer, Dordrecht, p 463-495

- Kromkamp JC, Forster RM (2003) The use of variable fluorescence measurements in aquatic ecosystems: differences between multiple and single turnover measuring 
protocols and suggested terminology. Eur J Phycol 38: 103-112

- Lesser M (1996) Acclimation of phytoplankton to UV-B radiation: oxidative stress and photoinhibition of photosynthesis are not prevented by UV-absorbing compounds in the dinoflagellate Prorocentrum micans. Mar Ecol Prog Ser 132:287-297

> Lesser MP, Cullen JJ, Neale PJ (1994) Carbon uptake in a marine diatom during acute exposure to ultraviolet $B$ radiation: relative importance of damage and repair. J Phycol 30:183-192

> Leustek T, Saito K (1999) Update on biochemistry sulfate transport and assimilation in plants. Plant Physiol 120: 637-644

Li Y, Horsman M, Wu N, Lan C, Dubois-Calero N (2008) Biofuels from microalgae. Biotechnol Prog 24:815-820

> Litchman E, Neale PJ, Banaszak AT (2002) Increased sensitivity to ultraviolet radiation in nitrogen-limited dinoflagellates: photoprotection and repair. Limnol Oceanogr 47:86-94

Logan BA, Demmig-Adams B, Rosenstiel TN, Adams WW III (1999) Effect of nitrogen limitation on foliar antioxidants in relationship to other metabolic characteristics. Planta 209:213-220

> Malanga G, Puntarulo S (1995) Oxidative stress and antioxidant content in Chlorella vulgaris after exposure to ultraviolet-B radiation. Physiol Plant 94:672-679

> Malanga G, Calmanovici G, Puntarulo S (1997) Oxidative damage to chloroplasts from Chlorella vulgaris exposed to ultraviolet-B radiation. Physiol Plant 101:455-462

Mata TM, Almeida R, Caetano NS (2013) Effect of the culture nutrients on the biomass and lipid productivities of microalgae Dunaliella tertiolecta. Chem Eng Sci 32:973-978

McKenzie RL, Aucamp PJ, Bais AF, Björn LO, Ilyas M, Madronich S (2011) Ozone depletion and climate change: impacts on UV radiation. Photochem Photobiol Sci 10: 182-198

> Melis A, Zhang L, Forestier M, Ghirardi ML, Seibert M (2000) Sustained photobiological hydrogen gas production upon reversible inactivation of oxygen evolution in the green alga Chlamydomonas reinhardtii. Plant Physiol 122:127-136

> Meng X, Yang J, Xu X, Zhang L, Nie Q, Xian M (2009) Biodiesel production from oleaginous microorganisms. Renew Energy 34:1-5

> Menon KR, Balan R, Suraishkumar GK (2013) Stress induced lipid production in Chlorella vulgaris: relationship with specific intracellular reactive species levels. Biotechnol Bioeng 110:1627-1636

Mitchell D, Karentz D (1993) The induction and repair of DNA photodamage in the environment. In: Young A, Moan J, Björn L, Nultsch W (eds) Environmental UV photobiology. Springer, New York, NY, p 345-377

Murata N, Takahashi S, Nishiyama Y, Allakhverdiev SI (2007) Photoinhibition of photosystem II under environmental stress. Biochim Biophys Acta 1767:414-421

- Navarro E, Robinson CT, Wagner B, Behra R (2007) Influence of ultraviolet radiation on UVR-absorbing compounds in freshwater algal biofilms and Scenedesmus vacuolatus cultures. J Toxicol Environ Health A 70: 760-767

Navarro E, Robinson CT, Behra R (2008) Increased tolerance to ultraviolet radiation (UVR) and cotolerance to cadmium in UVR-acclimatized freshwater periphyton. Limnol Oceanogr 53:1149-1158
Navarro E, Muñiz S, Korkaric M, Wagner B, de Cáceres M, Behra R (2014) Ultraviolet radiation dose calculation for algal suspensions using UVA and UVB extinction coefficients. J Photochem Photobiol B 132:94-101

> Niyogi KK, Björkman O, Grossman R (1997) The roles of specific xanthophylls in photoprotection. Proc Natl Acad Sci USA 94:14162-14167

Nilawati J, Greenberg BM, Smith REH (1997) Influence of ultraviolet radiation on growth and photosynthesis of two cold ocean diatoms. J Phycol 33:215-224

Pessoa MF (2012) Harmful effects of UV radiation in algae and aquatic macrophytes - a review. Emirates J Food Agric 24:510-526

Rijstenbil J (2001) Effects of periodic, low UVA radiation on cell characteristics and oxidative stress in the marine planktonic diatom Ditylum brightwellii. Eur J Phycol 36: $1-8$

- Rijstenbil J (2002) Assessment of oxidative stress in the planktonic diatom Thalassiosira pseudonana in response to UVA and UVB radiation. J Plankton Res 24:1277-1288

Rosales-Loaiza N, Guevara M, Lodeiros C, Morales E (2008) Crecimiento y producción de metabolitos de la cianobacteria marina Synechococcus sp. (Chroococcales) en función de la irradiancia. Rev Biol Trop 56:421-429

Schenk H, Hanf J, Neumüller M (1983) The phycobiliproteins in Cyanophora paradoxa as accessory pigments and nitrogen storage. Z Naturforsch C Biosci 38:972-977

Schreiber U, Bilger W, Neubauer C (1995) Chlorophyll fluorescence as a nonintrusive indicator for rapid assessment of in vivo photosynthesis. In: Schulze ED, Caldwell MM (eds) Ecophysiology of photosynthesis. Springer Study Edition Vol 100, Springer-Verlag, Berlin, p 47-70

Schultz HR (2000) Climate change and viticulture: a European perspective on climatology, carbon dioxide and UV-B effects. Aust J Grape Wine Res 6:2-12

> Sharma KK, Schuhmann H, Schenk PM (2012) High lipid induction in microalgae for biodiesel production. Energies 5:1532-1553

Shick JM, Dunlap WC (2002) Mycosporine-like amino acids and related gadusols: biosynthesis, accumulation and UV-protective functions in aquatic organisms. Annu Rev Physiol 64:223-262

Smart CM (1994) Gene expression during leaf senescence. New Phytol 126:419-448

> Sobrino C, Montero O, Lubián LM (2004) UV-B radiation increases cell permeability and damages nitrogen incorporation mechanisms in Nannochloropsis gaditana. Aquat Sci 66:421-429

Sobrino C, Neale PJ, Lubián LM (2005) Interaction of UV radiation and inorganic carbon supply in the inhibition of photosynthesis: spectral and temporal responses of two marine picoplankters. Photochem Photobiol 81: 384-393

Sorokin C, Krauss RW (1958) The effects of light intensity on the growth rates of green algae. Plant Physiol 33: $109-113$

Stengel DB, Connan S, Popper ZA (2011) Algal chemodiversity and bioactivity: sources of natural variability and implications for commercial application. Biotechnol Adv 29:483-501

> Talarico L, Maranzana G (2000) Light and adaptative responses in red macroalgae: an overview. J Photochem Photobiol B 56:1-11

Tandeau de Marsac N, Houmardd J (1993) Adaptation of cyanobacteria to environmental stimuli: new steps 
towards molecular mechanisms. FEMS Microbiol Rev 104:119-190

Tredici MR (2010) Photobiology of microalgae mass cultures: understanding the tools for the next green revolution. Biofuels 1:143-162

Utermöhl H (1958) Zur Vervollkommnung der quantitativen Phytoplankton-Methodik. Mitt Int Ver Theor Angew Limnol 9:1-38

Van De Poll W, Van Leeuwe M, Roggeveld J, Buma AGJ (2005) Nutrient limitation and high irradiance acclimation reduce PAR and UV-induced viability loss in Antarctic diatom Chaetoceros brevis (Bacillariophyceae). J Phycol 41:840-850

Villafañe VE, Sundbäck K, Figueroa FL, Helbling EW (2003) Photosynthesis in the aquatic environment is affected by UVR. In: Helbling EW, Zagarese HE (eds) UV effects in aquatic organisms and ecosystems. Royal Society of Chemistry, Cambridge

Vincent WF, Neale PJ (2000) Mechanisms of UV damage to aquatic organisms. In: de Mora S, Demers S, Vernet M (eds) The effects of UV radiation in the marine environment. Cambridge University Press, New York, NY, p 149-176

Watanabe S, Sudo K, Nagashima T, Takemura T, Kawase H, Nozawa T (2011) Future projections of surface UV-B in a changing climate. J Geophys Res 116:D16118, doi: 10.1029/2011JD015749

Wellburn AR (1994) The spectral determination of chlorophylls $a$ and $b$, as well as total carotenoids, using various solvents with spectrophotometers of different resolution.

Submitted: December 13, 2013; Accepted: August 6, 2014
J Plant Physiol 144:307-313

> Wilhelm C, Jakob T (2011) From photons to biomass and biofuels: evaluation of different strategies for the improvement of algal biotechnology based on comparative energy balances. Appl Microbiol Biotechnol 92:909-919

Wu H, Gao K, Ma Z, Watanabe T (2005) Effects of solar ultraviolet radiation on biomass production and pigment contents of Spirulina platensis in commercial operations under sunny and cloudy weather conditions. Fish Sci 71: $454-456$

Wulff A, Sundba K, Nilsson C, Underwood GJC (2000) Effects of UVB radiation on a marine microphytobenthic community growing on a sand-substratum under different nutrient conditions. Limnol Oceanogr 45:1144-1152

Yeh KL, Chang JS (2012) Effects of cultivation conditions and media composition on cell growth and lipid productivity of indigenous microalga Chlorella vulgaris ESP-31. Bioresour Technol 105:120-127

Young EB, Beardall J (2003) Photosynthetic function in Dunaliella tertiolecta (Chlorophyta) during a nitrogen starvation and recovery cycle. J Phycol 905:897-905

Yu J, Tang X, Zhang P, Tian J, Cai H (2004) Effects of $\mathrm{CO}_{2}$ enrichment on photosynthesis, lipid peroxidation and activities of antioxidative enzymes of Platymonas subcordiformis subjected to UV-B radiation stress. Acta Bot Sin 46:682-690

> Zhang L, Happe T, Melis A (2002) Biochemical and morphological characterization of sulfur-deprived and $\mathrm{H}_{2}$-producing Chlamydomonas reinhardtii (green alga). Planta 214:552-561

Proofs received from author(s): October 10, 2014 